\title{
THE ELUSIVE QUEST FOR HIGH INCOME STATUS - MALAYSIA AND THAILAND IN THE POST-CRISIS YEARS
}

DOI:

10.1016/j.strueco.2017.11.007

Document Version

Accepted author manuscript

Link to publication record in Manchester Research Explorer

\section{Citation for published version (APA):}

Sen, K., \& Tyce, M. (2017). THE ELUSIVE QUEST FOR HIGH INCOME STATUS - MALAYSIA AND THAILAND IN THE POST-CRISIS YEARS. Structural Change and Economic Dynamics.

https://doi.org/10.1016/j.strueco.2017.11.007

\section{Published in:}

Structural Change and Economic Dynamics

\section{Citing this paper}

Please note that where the full-text provided on Manchester Research Explorer is the Author Accepted Manuscript or Proof version this may differ from the final Published version. If citing, it is advised that you check and use the publisher's definitive version.

\section{General rights}

Copyright and moral rights for the publications made accessible in the Research Explorer are retained by the authors and/or other copyright owners and it is a condition of accessing publications that users recognise and abide by the legal requirements associated with these rights.

\section{Takedown policy}

If you believe that this document breaches copyright please refer to the University of Manchester's Takedown Procedures [http://man.ac.uk/04Y6Bo] or contact uml.scholarlycommunications@manchester.ac.uk providing relevant details, so we can investigate your claim.

\section{OPEN ACCESS}


THE ELUSIVE QUEST FOR HIGH INCOME STATUS - MALAYSIA AND THAILAND IN THE POST-CRISIS YEARS

\title{
KUNAL SEN (GLOBAL DEVELOPMENT INSTITUTE, UNIVERSITY OF MANCHESTER) AND MATT TYCE (GLOBAL DEVELOPMENT INSTITUTE, UNIVERSITY OF MANCHESTER)
}

\begin{abstract}
:
Both Malaysia and Thailand were seen to be part of the miracle growth economies of East Asia and fast moving into high income status in the early 1990s. Following the Asian Financial Crisis (AFC) of the mid 1990s, both countries have observed prolonged growth slowdowns. In this paper, we offer a political economy explanation of the growth slowdown in Malaysia and Thailand in their post AFC phases. We argue that the nature of the political settlement in these two countries determined a growth strategy that was predicated on offering deals in the export-oriented manufacturing sector that was accessible to most firms, at the same time, offering closed deals to politically connected firms in the natural resource and services sectors. As the political settlement moved to a vulnerable authoritarian one in both countries, such a dualistic deals strategy became patronage based over time and detrimental to growth.
\end{abstract}

\section{Introduction}

Very few developing countries have made the transition to middle income to high income status. In contrast to the experience of the early developers (Korea, Singapore and Taiwan), many developing countries currently are stuck in a "middle income trap", where economic growth started slowing down after a period of rapid sustained growth (World Bank 2016). ${ }^{1}$ In the early 1990s, it was widely believed that Malaysia and Thailand would make successful transition to high income status (World Bank 1993). During the 1950s to the early 1990s, both countries had growth rates that were among the highest in the world in that period, driven in large part by the rapid growth of an export oriented manufacturing sector. This growth acceleration phase was accompanied by significant structural transformation, as measured by manufacturing value-added as a share of GDP and the product complexity of exports. Outside the North East Asian miracle economies, there were few other countries in this period that had such impressive rates of structural transformation.

However, with the onset of Asian Financial Crisis (AFC) in 1996/1997, economic growth plummeted in these two countries, as in other countries that had seen rapid growth till that point, such as Indonesia and Korea. The growth deceleration episode from the mid-1990s to

\footnotetext{
${ }^{1}$ As the World Bank (2012) notes, of the 101 middle income countries in 1960, only 13 had graduated to high income status by 2008.
} 
date was accompanied by an investment collapse, stagnating manufacturing exports and in the case of Malaysia, a falling rate of structural transformation. While it was widely believed that the initial recession would be short lived and rapid economic growth would return to these two countries (as it did in Korea), the growth slowdown has now persisted for two decades. Both countries are seen to be characterised by the "middle income trap" (See Cherif and Hasanov (2015) and Warr (2011) for Thailand). While most analysts point to proximate determinants of the "middle income trap" in Malaysia and Thailand such as slowing productivity and the inability to compete against low wage economies (Kharas and Kohli 2011), in this paper, we offer a political economy explanation of Malaysia and Thailand's growth slowdown in the post AFC phase. We propose a conceptual framework drawing from political settlements theory (Khan 2010) as well as contributions by Pritchett and Werker (2012) and Sen (2013), which we use to explain why growth decelerated in the post AFC phase, after a prolonged period of rapid economic growth. ${ }^{2}$

To construct our analysis of Malaysia and Thailand's political settlements, we build on the platform provided by influential studies such as Doner (2009) and Khan's (2010) for Thailand and Gomez (2016) and Weiss's (2016) for Malaysia, but deepen their analyses by fine-tuning some of their classifications and periodisations. Gomez (2016:572) and Weiss (2016) for example, argue that Malaysia has had a "single dominant party" operating in a "competitive-authoritarian political system" since the late-1980s, a slightly messy analysis that obscures important shifts by bundling several concepts together. By employing political settlement analysis, however, we break these concepts down, revealing that Malaysia's political settlement has moved through three distinct stages, with the country possessing a weakening dominant party in the 1980s and 1990s, a vulnerable authoritarian coalition following the AFC and an increasingly competitive settlement since the mid-2000s, all with different implications for the deals space. In terms of Thai politics, meanwhile, we agree with Donor and Ramsay (2000) and Khan's (2010) classification that Thailand transitioned to competitive-clientelism in 1973, but stress that it was a hybrid competitive settlement in which non-elected establishment elites such as the military and palace wielded significant

\footnotetext{
${ }^{2}$ Malaysia's per capita income is higher than Thailand's which may suggest that the growth experiences of these two countries are not comparable. However, we show in Section 2 of the paper that the growth experiences of the two countries are qualitatively similar, and provide an unifying political economy account of the growth experiences of Malaysia and Thailand.
} 
holding power, a feature of Thai politics they underplay. For this very reason, we also disagree with Khan's (2010) assessment that Thailand moved from competitive-clientelism to a dominant party settlement between 2001 and 2008 under Thaksin Sinawatra, as his ruling coalition largely excluded these factions.

We also go beyond these studies by breaking down the Malaysian and Thai private-sectors, offering the clearest picture yet of the dualistic deals strategies pursued in both countries. Gomez (2004), for example, brings attention to the crony capitalism that sustained politically-connected Malay conglomerates in Malaysia but not the open investment environment that firms in export-oriented manufacturing sectors enjoyed, while Donor (2009) and others demonstrate the opposite trend in their work on Thailand, focusing on the growth coalitions that emerged in the textiles, electronics and auto industries but neglecting the cronyistic deals that establishment-linked conglomerates - notably the Crown Property Bureau, the monarchy's investment arm, which receives almost no mention in the literature - struck with state officials in protected domains such as pharmaceuticals and petrochemicals.

We argue that two political economy factors played a key role in explaining the growth slowdown in Malaysia and Thailand. Firstly, the political settlements in the two countries moved from strong dominant party to vulnerable authoritarian (interspersed by an extended period of competitive clientelism in the case of Thailand), which meant the political elite in the two countries lacked the enforcement capacities to discipline politicallyconnected firms in "high rent" sectors and in the case of Malaysia, follow effective industrial policies that was need for further upgradation of technological capabilities. Secondly, as a consequence of the nature of the political settlement in these two countries, the political elite attempted to manage the trade-off between political stability and growth enhancing institutions (openness to foreign direct investment and trade) by offering deals in the export-oriented manufacturing sector that was accessible to most firms, while at the same time offering closed deals to politically connected firms in the natural resource and services sectors (and in the case of Malaysia, the auto sector as well). While this dualistic deals strategy served both countries well till the crisis, they became more patronage based over time and increasingly disordered, and therefore, detrimental to growth in the post AFC 
phase. Where these two countries differed in their post AFC growth experience was a relatively better performance of Thailand in structural transformation as compared to Malaysia. This was due to a the presence of a sufficiently strong Thai capitalist class in contrast to the lack of such a class in Malaysia, which itself was a function of the differences in the political settlement in the two countries.

The rest of the paper contains five sections. The next section briefly describes the growth and structural transformation experience of Malaysia and Thailand. In Section 3, we propose a conceptual framework that draws from political settlements theory and other recent political economy contributions. In Sections 4 and 5, we apply our framework to the growth experiences of Malaysia and Thailand in the pre-AFC and post-AFC phases respectively. In Section 6, we present the conclusions.

\section{Economic Growth and Structural Transformation in Malaysia and Thailand}

As Figure 1 makes clear, both Malaysia and Thailand have had extended growth acceleration periods, both starting in the 1950s and ending in the mid-1990s (1997 in the case of Malaysia and 1996 in the case of Thailand). In the growth acceleration phase, the annual average growth rate of GDP per capita was 4.9 per cent for Malaysia and 5.7 per cent for Thailand. Beginning in 1997 for Malaysia and 1996 for Thailand, both countries went into a growth deceleration phase, till date. The growth rate for Malaysia in 1997-2010 was 1.9 per cent, a drop of 3 percentage points from the previous growth rate. The growth rate for Thailand was 2.0 per cent, a drop of 3.7 percentage points from the previous growth rate.

Figure 1. Per Capita GDP (in US PPP dollars), Malaysia and Thailand 


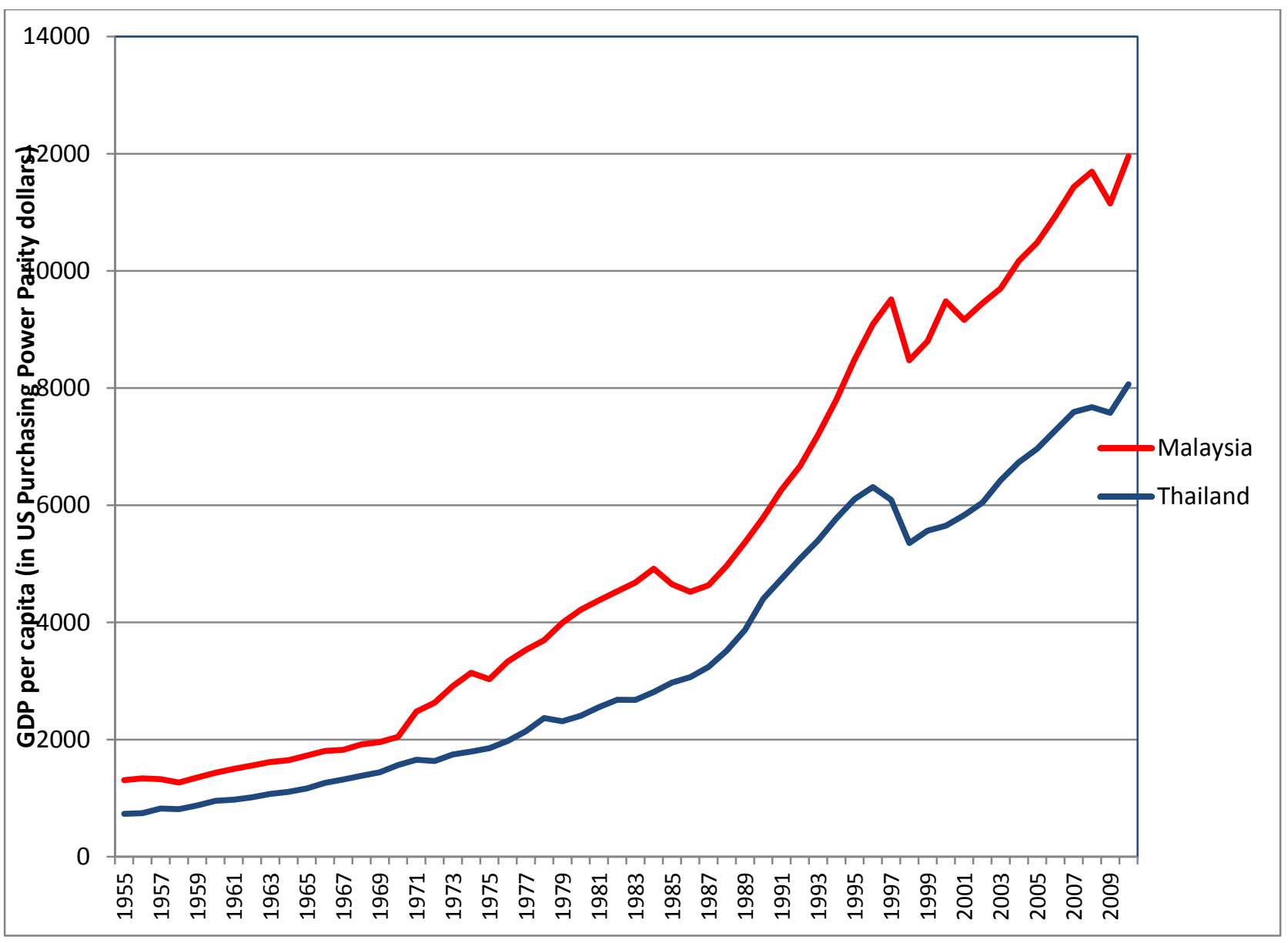

Source: World Bank, World Development Indicators.

Annual growth rates show similar growth trajectories, with major dips occurring largely as a result of exogenous factors such as the crash in commodity prices during the early 1970 s and early 1980s (both of which hit Malaysia hardest due to its reliance on oil exports), the 1997 AFC and the global financial crisis of 2007/08 (Figure 2).

Figure 2. Economic Growth in Malaysia and Thailand, 1956-2010 


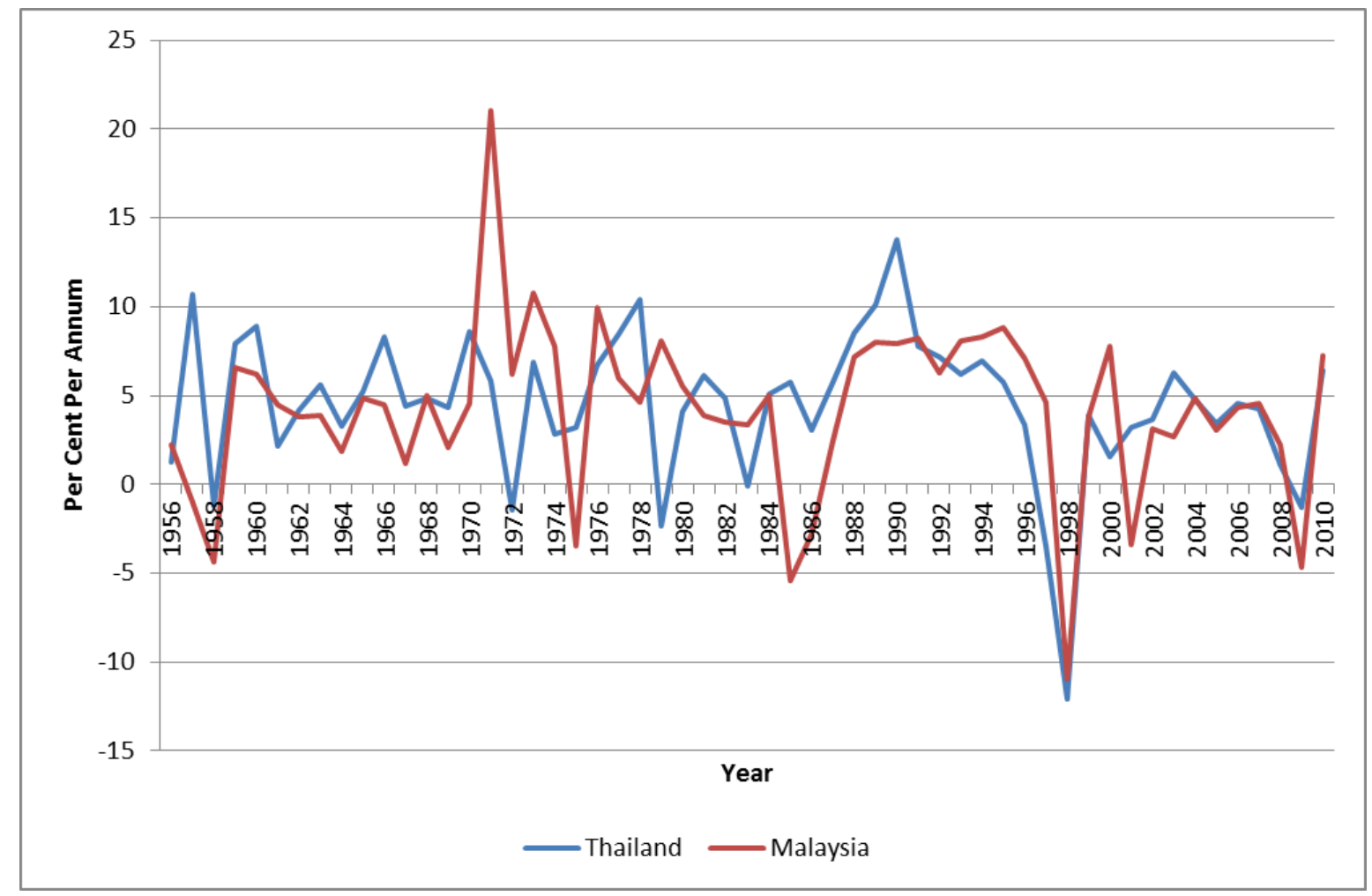

Source: World Bank, World Development Indicators.

A proximate cause of the fall in economic growth since the AFC was the decline in the investment rate in the two countries. Investment as a ratio of GDP rose steadily during the 1960s and 1970s in Malaysia and Thailand, before a surge in the mid-1980s (Figure 3). However, investment rates fell sharply from a high of over 40 per cent in the mid-1990s to around 25 per cent in the two countries in the 2000s, following the AFC. 
Figure 3. Investment rates as a percentage of GDP, 1960-2010

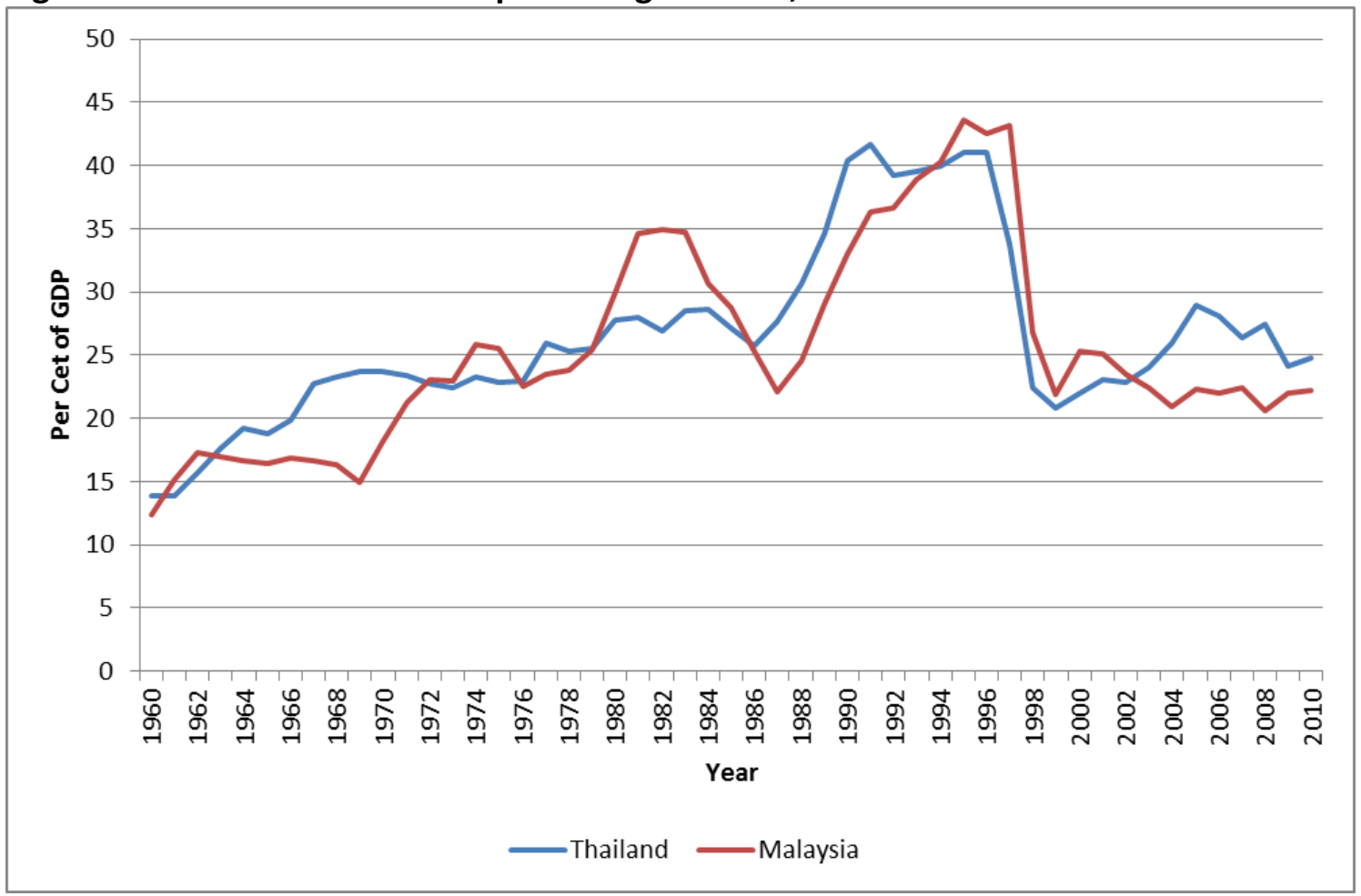

Source: World Bank, World Development Indicators.

A feature of Malaysia and Thailand's growth experience has been the high rates of structural transformation that has accompanied the rapid growth in these two countries. This is evident from the sustained increase in manufacturing value added as percentage of GDP since the 1960s in Malaysia and Thailand (Figure 4). The trend was broken at the turn of the century, however, as Malaysia experienced a clear decline, while Thailand has continued to rise steadily, though at a slower rate than in the pre-AFC phase. 
Figure 4. Manufacturing Value Added as a percentage of GDP, 1960-2010

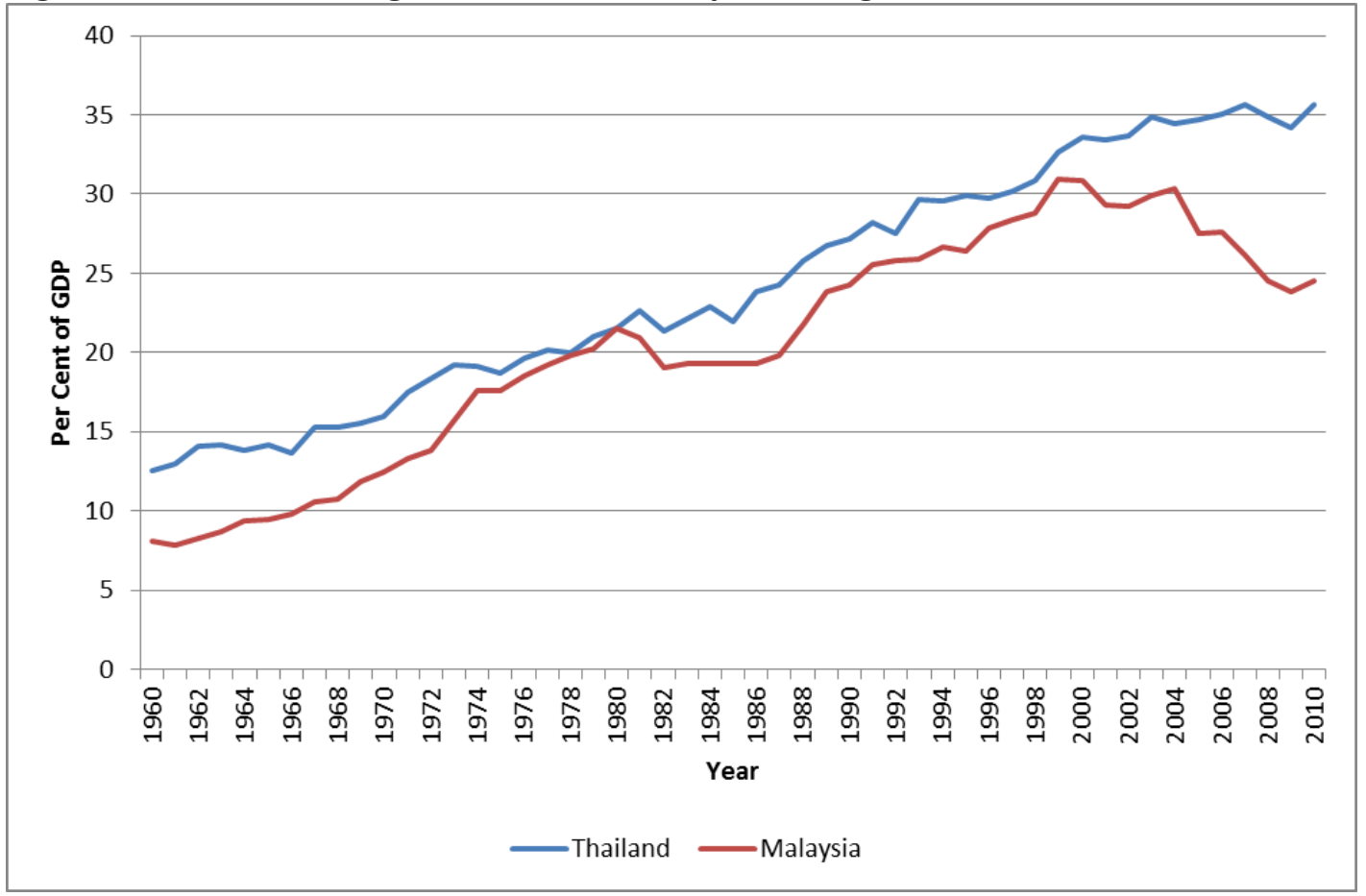

Source: World Bank, World Development Indicators.

Finally, examining the movement in the Hausmann-Hidalgo measure of economic complexity (a strong predictor of structural transformation), we see a sustained increase in this measure for both Malaysia and Thailand from the early 1970s (Figure 5). This increase was observed till the early 2000s. Beyond this date, we see that there has been no improvement in the economic complexity measure for Malaysia, while the measure shows further increase for Thailand for the 2000s, though at a lower rate of increase.

Overall, we find that both Malaysia and Thailand have had very similar growth experiences, in that both countries witnessed a prolonged period of rapid growth from the 1960s to the mid-1990s, before the onset of the AFC. Both these countries have seen a noticeable growth deceleration phase since the mid-1990s onwards. This has been reflected in surges in investment rates till the mid-1990s and then a sharp fall. Both these countries have seen significant structural transformation in the growth acceleration phase, as reflected in an increase in manufacturing value added as a share of GDP, and in the product complexity of exports. However, where these countries have parted ways has been in the nature of structural transformation in the growth deceleration phase. In Malaysia, there has been a 
slowdown and possible regress in structural transformation. ${ }^{3}$ This has not happened in Thailand to the same degree, with both indicators of structural transformation manufacturing value added as a share of GDP and the Hausmann-Hidalgo measure of economic complexity showing an improvement over time in the post-AFC phase, though the rate of improvement was not as impressive as what was observed in the growth acceleration phase. ${ }^{4}$

Figure 5. Hausmann-Hidalgo measure of economic complexity, Malaysia and Thailand, 1964-2013

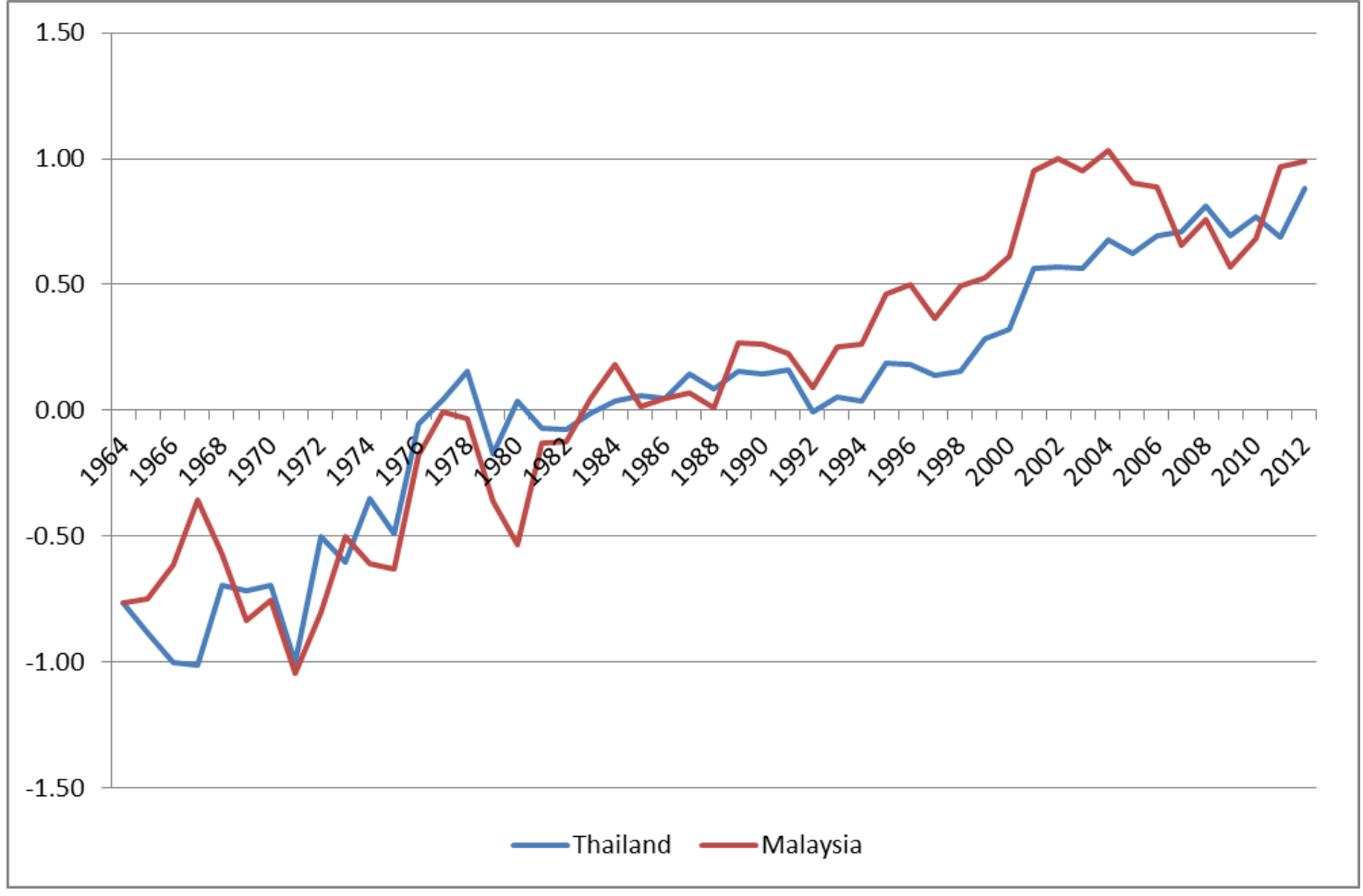

Source: The Atlas of Economic Complexity, http://atlas.cid.harvard.edu/, accessed 15 August 2016

\footnotetext{
${ }^{3}$ Most countries show a decline in manufacturing value added as a share of GDP at high levels of per capita income as the share of manufacturing in total output shows an inverted $U$ shaped curve over the course of development (Rodrik 2016). However, as Tan (2014:160) notes, "the turning point for manufacturing at around US\$4,000 GDP per capita in 2000 indicates that (Malaysia's) deindustrialisation is premature". The regress in structural transformation in the case of Malaysia is also indicated by the decline in the product complexity measure, as well as the decline in manufacturing output and productivity growth in the 2000s (Tan 2014). ${ }^{4}$ The Hausmann-Hidalgo measure is not without its problems as it does not differentiate between exports which are assembled in the country and where most of the inputs are mostly imported and exports where all the stages of production takes place in the country. Nevertheless, the Hausmann-Hidalgo measure is a good summary measure of economic complexity in the country's exports and is a good predictor of future income growth (Hidalgo and Hausmann 2009).
} 


\section{The Conceptual Framework}

Economic growth in developing countries is episodic -massive discrete changes in growth are common, with most developing countries experiencing distinct growth episodes and growth accelerations and decelerations or collapses as transitions between those episodes (Pritchett et al. 2016). In this section, we outline a conceptual framework drawn from Pritchett and Werker (2012) and Sen (2013) that can provide a political economy explanation of the episodic nature of growth in developing countries. Our framework has three core variables: the political settlement, the rent space, and the deals space.

Our first core variable is the political settlement, which Khan (2010) defines as "the interdependent combination of a structure of power and institutions at the level of a society that is mutually 'compatible' and also 'sustainable' in terms of economic and political viability.. In Khan's notion of political settlements, institutions and the distribution of power have a circular and interdependent relationship. Khan defines power as holding power - that is, "how long a particular organization can hold out in actual or potential conflicts against other organizations or the state" and where holding power is "a function of a number of characteristics of an organization, including its economic capability to sustain itself during conflicts, its capability to mobilize supporters to be able to absorb costs and its ability to mobilize prevalent ideologies and symbols of legitimacy to consolidate its mobilization and keep its members committed" ((Khan 2010, p. 20). The relationship between holding power and institutions is two way. The configuration of holding power at the level of society is supported by a range of formal and informal institutions that reproduce and sustain the specific configuration of relative power between organizations by enabling a consistent set of economic benefits to be created and allocated. In turn, relative power determines which institutions emerge, whether institutions are enforced, and what their effect is on economic performance. If the distribution of benefits by a particular institution is not accepted by groups who have high holding power, there would be opposition to the introduction of the institution or its enforcement would be contested, leading to a possible increase in political instability, even though the institution may be growth-enhancing. This suggests that for political stability to be maintained in a given country context, the prevailing political settlement must be well aligned with the distribution of rents that accrue to the different groups of elites that constitute the settlement.

Khan argues that the structure of the ruling coalition is important in explaining why some political settlements have greater enforcement capabilities than others. Two dimensions of power matter in understanding these capabilities. First, the horizontal distribution of power, which is the power of the ruling coalition relative to the power of excluded coalitions. Second, the vertical distribution of 
power, which is the relative power of higher compared to lower level factions within the ruling coalition. Figure 6 provides a schematic view of these two dimensions of power, and how they matter for the enforcement capabilities of the ruling coalition.

It is clear from Figure 6 that the most favourable combination in terms of the enforcement capabilities of the ruling coalition is when the ruling coalition faces low opposition from excluded factions so as to take a long-term view, allowing patron-client networks to be self-sustaining and growth focused. With limited power from lower level factions, the ruling coalition is able to exercise control across the entire pyramidical structure of the network to make sure that the network does not turn predatory. A concentrated horizontal distribution of power coupled with dispersed vertical distribution of power leads to a vulnerable authoritarian coalition that is always in the danger of being overthrown, while a concentrated vertical distribution of power coupled with dispersed horizontal distribution of power leads to a weak dominant party that may be growth oriented, but is unable to obtain 'buy-in' from the different lower level factions in using rents productively for growth. Finally, dispersion in both horizontal and vertical distribution of power can lead to 'competitive clientelism', leading to cycling of factions in power and in the shortening of the time horizon of patrons, leading to possible predation and a lack of economic growth.

Figure 6. The Distribution of Horizontal and Vertical Power in Dominant and Competitive Settlements

\begin{tabular}{|l|l|l|l|}
\hline \multicolumn{2}{|l|}{$\begin{array}{l}\text { VERTICAL/HORIZONTAL DISTRIBUTION } \\
\text { OF POWER }\end{array}$} & \multicolumn{2}{l}{$\begin{array}{l}\text { HORIZONTAL DISTRIBUTION OF POWER: POWER } \\
\text { OF EXCLUDED FACTIONS }\end{array}$} \\
\cline { 2 - 4 } & WEAK & STRONG \\
\hline $\begin{array}{l}\text { VERTICAL } \\
\text { DISTRIBUTION OF } \\
\text { POWER: POWER } \\
\text { OF LOWER LEVEL } \\
\text { FACTIONS }\end{array}$ & $\begin{array}{l}\text { STRONG DOMINANT } \\
\text { PARTY }\end{array}$ & $\begin{array}{l}\text { VULNERABLE } \\
\text { AUTHORITARIAN } \\
\text { COALITION }\end{array}$ \\
\cline { 2 - 4 } & STRONG & WEAK DOMINANT & $\begin{array}{l}\text { COMPETITIVE } \\
\text { CLIENTELIST }\end{array}$ \\
\hline
\end{tabular}

Source: Adapted from Khan (2010)

Our second core variable is the structure of economic opportunities in the economy, which we call the rents space. We divide the private sector along two dimensions, which capture the target market and the source of profitability respectively. First, do firms cater to domestic demand, or 
rather to use the country's factors of production to export to the rest of the world? Looking at major investments in developing countries, businesses generally have a value proposition to target just one or the other. Second, do they generate profits through discretionary rents under the control of politicians or bureaucrats, or through normal market competition, that is, by out-competing other firms? In many developing countries, due to the necessity of sharing rents among economic and political elites to maintain stability, most of the larger firms' bottom line is disproportionately driven by these "regulatory rents." Dividing the private sector along these two dimensions generates a rent space, with four distinct groups of firms, as in Figure 7.

Figure 7. The Rents Space
Regulatory rents
Market Competition

\begin{tabular}{|c|c|c|}
\hline $\begin{array}{l}\text { Export- } \\
\text { oriented }\end{array}$ & RENTIERS & MAGICIANS \\
\hline $\begin{array}{l}\text { Domestic } \\
\text { market }\end{array}$ & POWERBROKERS & WORKHORSES \\
\hline
\end{tabular}

Source: Pritchett and Werker (2012)

Regulatory rents are defined as those derived from some discretionary action of government, such as: offering licences for commercial use of a resource (e.g. mining), bestowing firm-specific (rather than industry-specific) tax advantages, market exclusivity, or application of applicable regulations. It could also be derived from deliberate government inaction such as permitting monopolies to charge prices significantly above marginal cost; or not enforcing anti-trust law or pursuing competitive markets when it would be appropriate for consumer welfare.

Firms operating in competitive industries may still earn rents, but those come from competitive strategies undertaken for the firm to make a better product at a higher margin, such as: brand differentiation, locational advantages, capital intensity, or increasing returns to scale generally. Rents in competitive industries can also be Schumpeterian - that is, rents deriving from innovation and information generation. Firms primarily compete against one another in product markets. When government offers industry-wide (e.g. car parts manufacturers) or special economic zone-wide tax advantages (tax holiday for ten years), for example, profitability may go up but the nature of competition is unchanged. 
The rentiers are the natural resource firms exporting to world commodity markets. Agricultural firms with concessions are usually here as well, since they get to use large tracts of land without going through formal property purchasing channels. In general, rentier firms sign agreements with the state, which essentially give them the right to sell the resources belonging to the state and its people-in exchange for a set of fees and taxes.

The magicians are the exporters that operate in competitive industries. They are labelled magicians since they make a market out of nothing (as opposed to firms serving the domestic population that can rely on a captive market). In a typical developing country, competitive-industry exports might include garments, manufactured goods, agricultural products, tourism, and processed items.

The powerbrokers are the firms catering to the domestic sector that operate in industries subject to regulatory rents. Most powerbrokers are in regulated industries (sometimes restricted to a single state-owned enterprise) that limit competition, like power provision, port operation, petroleum refining. Others survive off government contracts like heavy construction companies. Since powerbrokers know that they will be regulated, they tend to form close relationships with government. In many developing countries, firms that would otherwise be in a competitive market may lobby to get their own monopoly, and in doing so earn excess profits.

The workhorses are those firms operating in competitive markets that serve the domestic economy. Among the workhorses in a developing country are its subsistence farmers, livestock raisers, builders, restaurant owners, petty traders, hairdressers, village lenders, and some of its importers. Much of the time, they provide the vast majority of goods and services in the market-particularly those goods and services consumed by ordinary citizens. Many of the workhorses operate in the informal sector, utilizing shadow markets and traditional dispute mechanisms in order to enforce contracts.

This typology does not imply that rentiers and powerbrokers are bad, and that magicians and workhorses are good. Indeed, it may be the rentiers that provide the main engine of growth during growth accelerations. And it may be the powerbrokers that provide the essential services that give citizens access to trade, water, sanitation, electricity, and communication. But firms in each of these quadrants have different demands of the state, even (in fact, especially) of those states that do not enforce all of the rules. Understanding those divergent interests is important to understanding how the elites may or may not have an interest in growth.

Policy evolution in "deals" environments is essentially the outcome of the interaction between the political settlement, and the rent space. Powerbrokers are the classic force for red tape, where the impetus may come from strong politicians or bureaucrats creating rents for themselves or their 
cronies, or from strong businesspeople buying off politicians and bureaucrats to entrench their market position. The problem is that they advocate for policies that are detrimental to firms in the other quadrants.

When powerbrokers are strong, and decisive, the economy trends towards bad rules that create the differential advantages of the powerbrokers through selective enforcement for the "friends." When other economic actors are also strong, just not strong enough to set the rules, the situation trends towards not "good rules" but rather "poor enforcement", since strong enforcement would end up stifling the other sectors. Rentiers and workhorses end up not paying their taxes by an endless string of deals. In this environment "magicians" are all but excluded as the rent seeking behaviour of powerbrokers in non-tradable industries creates both bad rules and often high-cost infrastructure (e.g. by garnering rents from construction, monopolizing power or ports, etc.).

Our final core variable is the deals space, where deals are defined to be a specific action between two (or more) entities (or individuals) that is not the result of the impersonal application of a rule, but rather of characteristics or actions of specific entities which do not spill over with any precedential value to any other future transaction between other entities. In our framework, the deals space captures the range of informal and personalised relationships that are observed between economic actors and political elites in developing countries. An earlier literature on the institutional determinants of economic growth has focused on rules, which are de jure policies or formal (parchment) institutions such as courts and written contracts. However, the key feature that distinguishes "developing" countries is the gap between the official, formal, legal, de jure laws and regulations and what actually happens. The stated "rules of the game" have near zero predictive power for what will actually happen.

Table 1 divides these environments along two dimensions: whether deals, once negotiated, are honoured (ordered vs. disordered); and whether deals are widely available or limited to an elite (open vs. closed). Ordered deals are deals that, once negotiated between investors and state officials, are honoured. In this case, investors can be assured that the political elite can deliver on the deals they make with the latter. On the other hand, disordered deals are deals that investors make with the political elite, where there is no certainty that the deal will be delivered. Open deals are deals that are widely available to all investors, large or small, and not confined to an elite or a small group of favoured investors. On the other hand, closed deals are offered by the political elite only to a small group of investors. 


\begin{tabular}{|l|l|l|}
\hline \multicolumn{1}{|l|}{ Table 1. Typology of "deals" environments } \\
\hline & $\begin{array}{l}\text { Closed } \\
\text { (deals are available only to } \\
\text { specific } \\
\text { individuals/organizations) }\end{array}$ & $\begin{array}{l}\text { Open } \\
\text { (deals depend on actions of } \\
\text { agents but not identities) }\end{array}$ \\
\hline $\begin{array}{l}\text { Ordered (once negotiated, } \\
\text { deals will be honored) }\end{array}$ & $\begin{array}{l}\text { Only those with political } \\
\text { connections get to make deals, } \\
\text { but they can be confident that } \\
\text { officials will deliver }\end{array}$ & $\begin{array}{l}\text { Anyone can make a deal, and } \\
\text { they can be certain that officials } \\
\text { will deliver }\end{array}$ \\
\hline $\begin{array}{l}\text { Disordered (deals will be } \\
\text { honored so long as they are in } \\
\text { the short-term interests of } \\
\text { political elite) }\end{array}$ & $\begin{array}{l}\text { Only those with political } \\
\text { connections get to make deals, } \\
\text { certain that officials will } \\
\text { deliver }\end{array}$ & $\begin{array}{l}\text { Anyone can make a deal, but no } \\
\text { one certain that officials will } \\
\text { deliver }\end{array}$ \\
\hline
\end{tabular}

Source: Pritchett and Werker (2012)

\section{Towards a Theory of Episodic Growth}

We now have the building blocks in place to develop a political economy theory of episodic growth. In our framework, economic growth and the degree to which that growth is characterized by structural transformation is an outcome of the nature of deals (the intermediary variable) offered to economic actors. This in turn is a function of the political settlement and the rents space (the core variables) (Pritchett, Sen and Werker 2017).

Growth episodes then influence the political settlement and the rents space by positive or negative feedback loops which in turn impacts on the deals space, affecting future growth. We provide a schematic representation of the inter-relationships in Figure 8. 
Figure 8. The Inter-relationships between Political Settlements, the Rents Space and the Deals Space

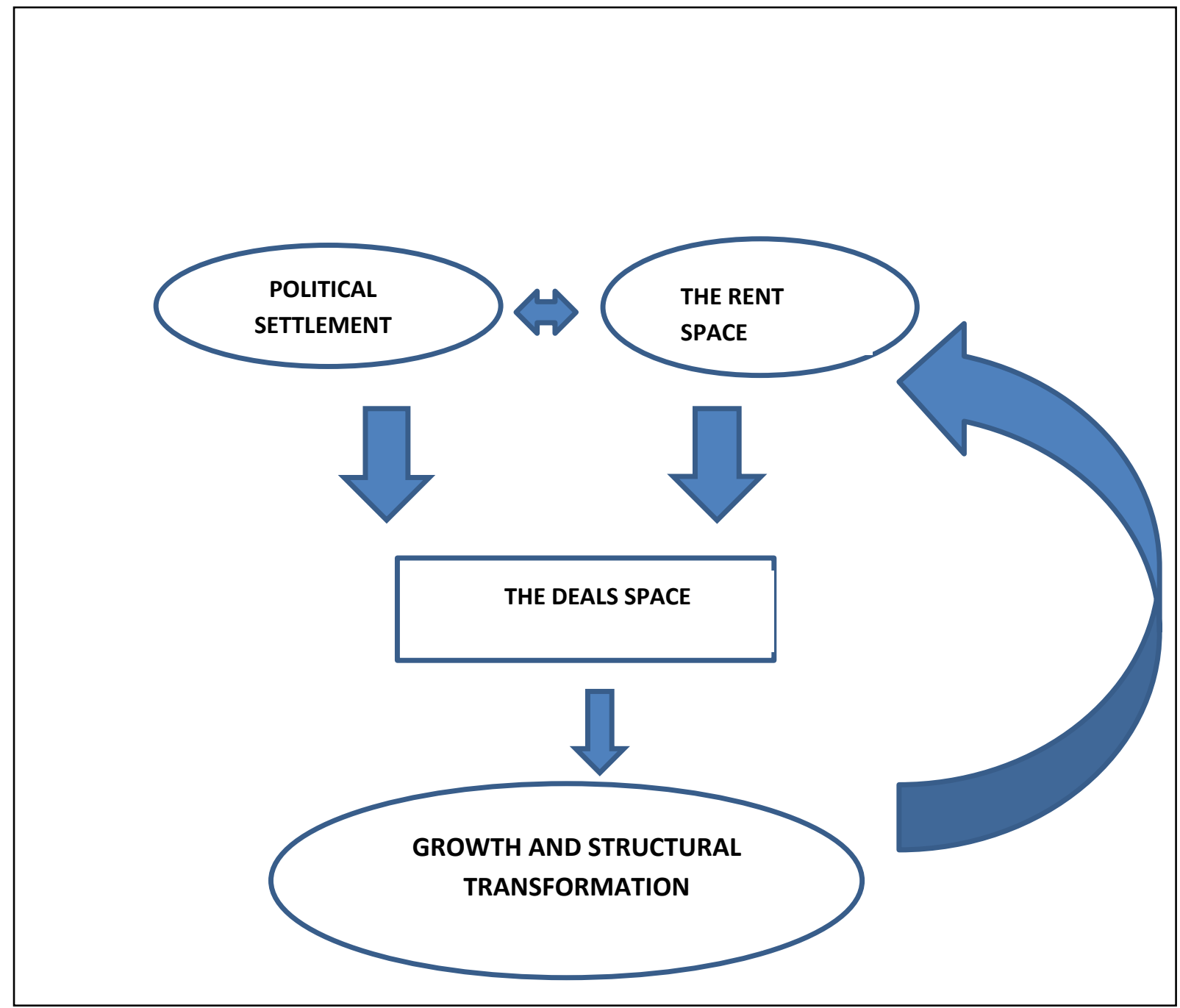


Source: Our illustration

According to our framework, economic growth is likely to accelerate when there is a movement in the deals space from disordered to ordered deals. Ordered deals mean that an investor's time horizon for realizing returns is lengthened, which makes a greater set of investments profitable in net present value. There may be an additional quid pro quo in which ordered deals allow the state to ask investors to commit to the investment decision and engage in production, so that rents can be generated through the production process. This commitment to ordered deals needs to be seen as credible by investors: they must believe that the state or its agents will not renege on its implicit or explicit promise not to expropriate future rents, especially after investment decisions involving sunk costs in fixed capital have been taken (Sen 2013).

A commitment to "ordered deals" is more likely in at least two situations. One of them corresponds to the "doorstep" conditions of North et al. (2009) when interactions among the elite begin to take place in a more impersonal manner; in our framework this would be most likely when the economy is further along in structural transformation, usually indicated by a larger share of workhorses and magicians, and supported by a political settlement whose legitimacy comes from economic growth and positive reforms. The other situation is orthogonal to these unambiguously positive outcomes. That is during dominant party political settlements, where a strong political leadership allows for the likelihood of deals, once negotiated, to be honoured (ordered deals) and credible commitment by elites to economic growth. The growth accelerations that occur during such political settlements may just as likely arise in rentier and powerbroker quadrants, and support an ever-more-exclusive political elite whose power comes from patronage or repression. To contrast with dominant party settlements, in competitive clientelism, due to cycling of factions in power, political time horizons are short, and credible commitment to ordered deals may not be present.

There is nothing pre-ordained in the evolution of institutions that suggest the move from closed ordered or disordered deals to open ordered deals is linear. As economic growth originates in a country, there are two feedback loops that occur from the growth process to the deals space. These feedback loops can be both positive or negative - in other words, whether with further economic growth, the deals space may turn from being open ordered to being closed ordered or being disordered. The first of these feedback loops is economic in nature and depends on whether the process of growth strengthens powerbrokers and rentiers relative to magicians and workhorses. Since rentiers and powerbrokers benefit from closed deals, a growth episode that empowered them 
would likely lead to a closing of the deals space. In such an episode, we would expect to see closer personalised relationships with the political elite, to capture the process of licence allocation or to create artificial barriers to entry. On the other hand, a growth episode that empowered magicians and workhorses would likely lead to an opening in the deals space. This is for two reasons. Firstly, these are sectors that are most dynamic and where "creative destruction" is most likely to occur, and where firms in these sectors would benefit the most from an open deals environment. Secondly, given the inherent contestability of these sectors and the presence of a large number of economic actors, a closed deals space that excludes many of these actors is not likely to find political traction. Finally, these two sectors depend on an efficient powerbroker sector for cheap and high quality inputs to their production process, such as well functioning roads and reliable electricity provision, and would benefit from the competitive pressures that an open deals environment would bring to powerbroker firms, thereby further weakening the powerbrokers.

The second of the feedback loops is political in nature and depends on nature of the political settlement and how it evolves over time. The evolution of the political settlement would depend on in part on the relative holding power of the political interests attached to firms in the different quadrants of the rent space, since they will set the terms of government capabilities and the deal space going forward, subject to the constraints of the settlement. In growth episodes where rentiers and powerbrokers gain influence, the feedback effect from the growth process is likely to be negative for institutional quality. The one potential exception is during a dominant party political settlement with strong enforcement capabilities in which the ruling coalition sees magicians and workhorses as politically salient for the purpose for maintaining growth (Khan 2010).

If the positive growth episode is underpinned by closed ordered deals that do not become open over time, it is likely that both the economic and political feedback loops will turn negative and the closed ordered deals may become increasingly disordered, bringing the positive growth episode to an end. On the other hand, economic and political feedback loops can be positive if the deals space becomes increasingly open, and the magician and workhorse sectors become increasingly important in the growth process, leading to rapid sustained growth. We depict the different possibilities in Figure 9, which sets out visually our framework for understanding episodicgrowth. 
Figure 9. A Framework for Understanding Growth Episodes

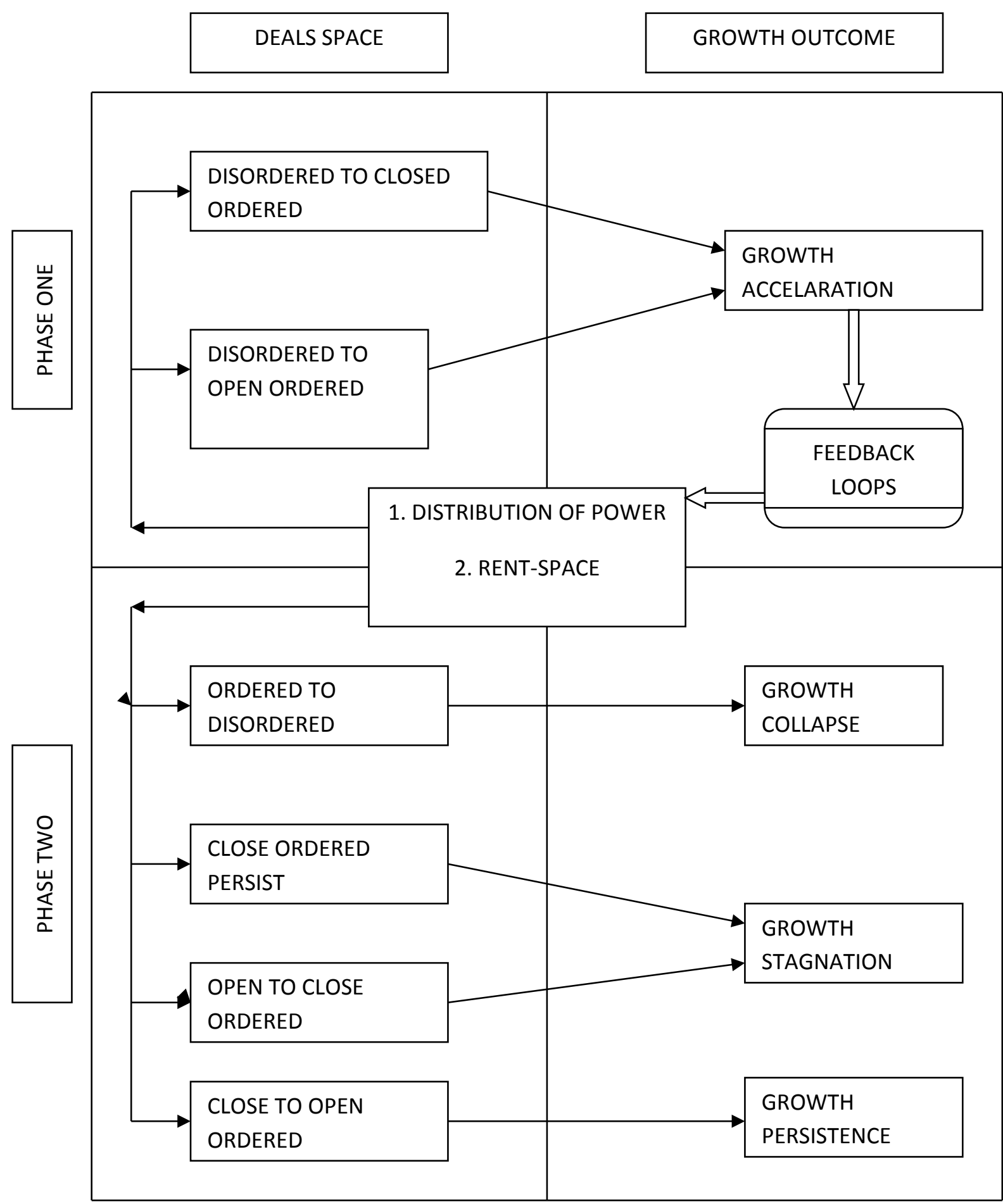

Source: Kar and Sen (2016)

The above characterisation of the deals space seems to suggest that developing countries will be in one of the four quadrants of Table 1 in terms of the deals offered by political elites to firms. However, in reality, it is far more likely that political elites "bifurcate" the deals 
space, by offering a set of deals to one group of firms, and a different set of deals to another group of firms. For example, political elites may offer closed ordered deals to politically connected firms in the rentier and powerbroker sectors and offer open ordered deals to magicians. The closed deals may be a reflection of rent sharing among economic and political elites to maintain political stability. On the other hand, the open ordered deals would be a way to encourage investment in the growth oriented sectors of the economy (such as export oriented manufacturing) which may then provide a larger "size of the cake" to be shared among economic and political elites. How political elites offer deals to different economic actors in the rents space would be a function of the political settlement, as well as the relative holding power of different sets of firms. This would have implications for growth and structural transformation, as we will see when we examine the growth experiences of Malaysia and Thailand. We do this next.

\section{The Growth Experience of Malaysia and Thailand in the Pre-AFC Phase}

In this section, we discuss the political economy factors the underpinned the growth accelerations of Malaysia and Thailand in the pre-AFC phase.

\section{Malaysia}

Our analysis begins in 1969, the year ethnic riots transformed Malaysian politics. Tensions had risen since independence in 1957, as Malay Bumiputera ("sons of the soil") became resentful towards Malaysia's relatively wealthy "immigrant" Chinese minority. However, tensions erupted following an election that saw Chinese voters desert the ruling coalition for an opposition party demanding an end to Malay special privileges enshrined in the constitution (Jesuadson 1990). Rioting began in Kuala Lumpur and spread throughout Malaysia, realigning the balance of power within its political settlement. After two years of martial law, the ruling coalition previously known as The Alliance - which consisted of three ethnically-based parties representing Malaysia's Malay, Chinese and Indian communities, all of which were accorded roughly equal status by a pre-independence power-sharing deal reinvented itself as the Barisan National (BN, "United Front") and incorporated several Malay opposition parties, simultaneously reducing the influence of the Chinese and Indian parties while cementing the United Malays National Organisation's (UMNO) status as the coalition's dominant force (Gomez 2004). 
With control over Malaysian politics - and Chinese interests in particular - the BN adopted an assertive pro-Malay stance called the New Economic Policy (NEP). Funded by taxing Malaysia's now politically-isolated Chinese capitalists, it sought to promote national unity through two mechanisms: first, by eradicating poverty regardless of race; second, by restructuring society to foster socioeconomic parity between ethnic groups (ibid). To achieve these objectives, the BN introduced a dualistic deals environment. Closed-ordered deals were offered to rentiers and powerbrokers, where the ability to shield them from competition allowed the $\mathrm{BN}$ to advance its restructuring goals (Cho 1999). In industries requiring little capital or expertise, and where it had tight control over licenses and contracts - notably construction, logging, rubber, trade and transport - the BN promoted Malay SMEs. In capital-intensive industries, trust agencies were mandated with acquiring assets and holding them until Bumiputera capitalists emerged. Such was their success that, by 1982 , these agencies controlled $60 \%$ of plantation and mining activity, in addition to making inroads into powerbroker sectors such as cement, hotels, property and finance (Jesuadson 1990). Open-ordered deals, meanwhile, were offered to magicians to foster growth and employment, and achieve the goal of eradicating poverty. Owing to sensitivities of relying on Chinese firms, the BN attracted foreign magicians with generous incentives in the Investment Incentives and Free Trade Zone Acts unveiled in 1971. The former provided tax relief and pioneer status to priority industries including electronics and textiles while the latter offered tariff and customs exemptions as well as infrastructural support to firms in newly-created EPZs.

The dualistic deals strategy became more pronounced under Mohamed Mahathir, a highlyauthoritarian Prime Minister elected in 1981. Inspired by South Korean strongman Park Chung-Hee, he centralised power within the executive and utilised his control over state organs to enforce a shift in development policy (Gomez 2004). Critical of the NEP for encouraging a "subsidy mentality" amongst Malays, and for escalating public-spending to a point where it triggered a recession in 1985, he narrowed the range of rentier and powerbroker beneficiaries, channelling rents and contracts to an elite industrial class that could symbolise Malay prosperity. Notably, the Heavy Industry Corporation of Malaysia (HICOM) was established; backed by enormous resources, it was to spearhead 
industrialisation by investing in cement factories, iron and steel works, petrochemical plants and Proton, the national automobile manufacturer. In reality, however, Proton became little more than a vehicle for dispensing patronage to a "politically influential minority" (Gomez and Jomo 1997:1). Nevertheless, while deals closed for rentiers and powerbrokers, they opened further for magicians, with a 1986 Investments Promotion Act providing ten-year tax holidays and relaxed foreign equity restrictions for priority industries.

Positive and negative feedback characterised Malaysia's acceleration episode. Openordered deals for magicians led to an influx of FDI, particularly after 1985 when the surging Yen forced Japanese firms abroad. As magicians became increasingly influential, they demanded increasingly open deals, with Mahathir not only unveiling the Promotion of Investments Act in response to their demands, but relaxing foreign equity stipulations, liberalising the tax code and turning the Malaysian Investment Development Authority into an effective one-stop shop (Ritchie 2005). Negative feedback, meanwhile, was political in nature, resulting from closed deals offered to rentiers and powerbrokers. By the late-1980s, most prominent capitalists were intimately connected with - and owed their continuing success to - UMNO heavyweights, with the result that huge groups of interlocking corporate interests were cohered around senior politicians. With "power agglomerated at the top", fractures emerged as factions jostled for rents (Jesudason 1990:117). Initially these disputes were contained within the BN, such as in 1984 when there was a bitterly-fought contest for the deputy-presidency between Deputy Prime Minister Hitam and Finance Minister Razaleigh, and in 1987 when they united in a bid to unseat Mahathir. However, powerstruggles became increasingly irreconcilable, to the extent that Razaleigh formed an opposition party in 1990, only returning in 1995 with the lure of prominent positions. Though these internal machinations were not at this time threatening the BN's longevity, with Malaysia possessing a strong dominant party throughout the period, they provide an important backdrop to the shifts that occurred in Malaysia's political settlement after 1996 (Figure 10). 
Figure 10. Malaysia's Political Settlement, 1957-1996

\begin{tabular}{|c|c|c|c|}
\hline \multicolumn{4}{|c|}{ Horizontal Distribution of Power } \\
\hline \multirow{4}{*}{ 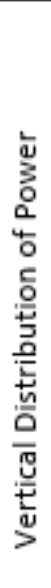 } & & Weak & Strong \\
\hline & & Strong Dominant Party & Vulnerable Authoritarian Coalition \\
\hline & $\sum_{3}^{\frac{1}{00}}$ & $\begin{array}{l}\text { Malaysia retains a Strong Dominant Party } \\
\text { throughout its acceleration episode, but shifts } \\
\text { towards a Vulnerable Authoritarian Coalition } \\
\text { as the BN suffers from a number of internal } \\
\text { fractures during the } 1980 \text { s and } 1990 \text { s }\end{array}$ & \\
\hline & $\begin{array}{l}\text { co } \\
\text { 든 } \\
\text { 点 }\end{array}$ & Weak Dominant Party & Competitive Clientelism \\
\hline
\end{tabular}

Source: Our illustration

\section{Thailand}

Our analysis of Thailand's acceleration episode also begins with a period of unrest - the 1973 riots. In contrast to Malaysia, however, they were not triggered by ethnic resentments, but disaffection with military rule that had endured since 1957, when Field Marshal Sarit Thanarat launched a coup and established a system of "despotic paternalism" (Warr 1993:11). The riots overturned the ruling coalition and shifted Thailand's political settlement from a strong dominant party to competitive-clientelism (Figure 11) though this was a hybrid competitive settlement in which extra-parliamentary actors - the so called "unelected elites", notably the palace and military - retained holding power that they deployed regularly through the mechanism of a coup (Kanchoochat 2014). Indeed, between the advent of competitive-clientelism and the end of Thailand's acceleration episode, no coalition survived for two terms without being brought down by a coup or militaryinstigated no confidence vote. The exception was former General Prem Tinsulanonda's coalition which governed between 1979 and 1988 because Prem crafted a delicate powersharing deal between his allies in the military and palace and Kukrit Pramoj's Social Action Party, which represented a plethora of emerging business interests. 
Figure 11. Thailand's Political Settlement, 1957-1996

\begin{tabular}{|c|c|c|c|}
\hline \multicolumn{4}{|c|}{ Horizontal Distribution of Power } \\
\hline \multirow{4}{*}{ 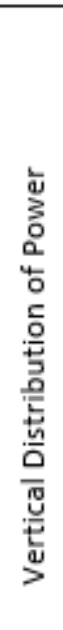 } & & Weak & Strong \\
\hline & & Strong Dominant Party & Vulnerable Authoritarian Coalition \\
\hline & $\frac{\text { 尊 }}{3}$ & $\begin{array}{l}\text { 1957-1973: Sarit and his } \\
\text { successors preside over a } \\
\text { system of despotic paternalism } \\
\text { that emphasises stability and } \\
\text { order over democratic } \\
\text { institutions }\end{array}$ & \\
\hline & $\begin{array}{l}\text { 巳n } \\
\text { 로 } \\
\text { 㟧 }\end{array}$ & Weak Dominant Party & $\begin{array}{l}\text { Competitive Clientelism } \\
\begin{array}{l}\text { 1973-1996: Riots overturn the military } \\
\text { junta and usher in a period of } \\
\text { competitive-clientelism }\end{array}\end{array}$ \\
\hline
\end{tabular}

Source: Our illustration

Despite the political flux, deals remained ordered because Thailand has a technocratic tradition stretching back to the nineteenth century. Hemmed in by colonial powers, and resolving that financial sustainability was essential for maintaining sovereignty, King Chulalongkorn launched a state reform programme which gave birth to a modern technocracy (Doner 2009). These reforms endowed generations of ruling and bureaucratic elites with ideological preferences for macroeconomic stability and fiscal caution, and are instrumental for understanding why the Finance Ministry and Bank of Thailand remained autonomous for much of Thailand's acceleration episode.

Following the 1973 riots, a dualistic deals environment like Malaysia's emerged, though it was not as distinct - or indeed as deliberate. Closed-ordered deals characterised rentier and powerbroker industries such as timber, rice-milling, property, retail and pharmaceuticals, where the establishment - particularly the palace through its investment arm the Crown Property Bureau (CPB) - developed substantial interests during the Sarit years (Raquiza 2012). Retaining closed deals in these domains was essential for the longevity of any incoming coalition not wanting to be overthrown by the military. Magicians, on the other hand, enjoyed open deals. Contrasting with Malaysia, such deals were not initially a 
conscious decision but an accident arising from Thailand's shift to a unique variant of competitive-clientelism. Between 1973 and 1978, rapid turnover of coalitions - and with them bureaucrats in sectoral ministries such as Agriculture, Commerce and Industry created an environment in which "many centres of state regulatory control and their links to different political factions ensured that no single firm or group of firms could block competition" (Unger 1998:125). As Doner and Ramsay note (2000:154), this "type of clientelism tended to expand, rather than restrict, opportunities" in industries such as textiles and electronics which were not dominated by establishment-linked firms.

Initially an accident, offering open-ordered deals to magicians became explicit under Prem as he launched an export-led industrialisation strategy that responded to shifting global conditions and limitations of ISI (Warr 1993). In addition to macroeconomic reforms such as currency devaluation and unleashing a wave of liberalisation, Prem reconfigured the Board of Investment (BOI) so it doled out incentives to textiles, electronics and automobile firms. As in Malaysia, EPZs figured prominently; firms located in them enjoyed relaxed labour laws, tax exemptions and infrastructural support. Nonetheless, the dualistic deals strategy remained in place, with Prem retaining closed deals for his allies in their traditional industries as well as emerging ones such as petrochemicals (ibid).

Similar to Malaysia's acceleration episode, Thailand experienced positive and negative feedback. As Thailand's private-sector grew it became increasingly organised, with business associations emerging (Doner 2009). In response to the demands of Thailand's peak association, The Association of Thai Industries, Prem established - and chaired the meetings of - the Joint Public and Private Sector Consultative Committee, which remedied numerous export obstacles. Sectoral associations also successfully lobbied the government. The Garment Manufacturers Association, for example, pressured it into developing local cotton and worked with the Export Promotion Department to identify new markets that eased overproduction issues and enhanced value-added production. In automobiles and electronics, suppliers lobbied for local content requirements that were, despite initial resistance from MNCs, relatively successful in generating linkages due to the time-bound targets set by the BOI (Natsuda and Thoburn 2012). 
As in Malaysia, negative feedback was political. Prem retired from frontline politics in 1988, leaving a power vacuum as subsequent Prime Ministers struggled maintaining the powerbalance he crafted. A government stacked with businessmen-cum-politicians lasted less than three years before being overthrown by the military in 1991, while the junta replacing it managed a year before rioting forced the King to demand its dissolution. Thailand then saw three profoundly unstable elected governments between 1992 and 1997, each of which failed to survive a full-term. As Hewison (1997:2) notes, unrestrained "money politics" emerged during these years, with money becoming vital for bringing coalitions to power and keeping them there. Indeed, Thais characterise the period as a series of "buffet cabinets", referring to the eagerness with which politicians helped themselves to state resources (Marshall 2014:94). So corrosive was the political climate that even the macroeconomic cornerstones were undermined. Technocrats were replaced with political appointees, resulting in increasingly disordered deals and a rapid decline in the management of the economy (Raziah 2012). Where Prem's eight-year tenure saw three Finance Ministers, the following ten saw thirteen hold the position. Even the previously incorruptible Central Bank became embroiled in a series of scandals, including the bailout of a politically-connected bank that would have been unthinkable previously.

\section{The Growth Experience of Malaysia and Thailand in the Post-AFC Phase}

In this section, we analyse Malaysia and Thailand's post-AFC deceleration episodes from the viewpoint of our conceptual framework. We discuss the evolution of the political settlement and rents space in Malaysia, and how these variables explain the evolution of the deals space and feedback loops, followed by a discussion of the same variables in Thailand.

\section{Malaysia}

\section{Political Settlement}

While power-struggles had undermined the BN since the late-1980s, it was only after the AFC - and particularly the imprisonment of Deputy Prime Minister Anwar Ibrahim - that an outright rupture occurred. Nominally, differences had arisen over how to deal with the crisis, as Anwar was reluctant to bailout Bumiputera conglomerates while Mahathir, swayed by ethno-political considerations, argued that failure to do so would jeopardise Bumiputera interests. Just as importantly, however, Mahathir believed Anwar was using the crisis as a 
pretext to challenge his leadership (Gomez 2004). Either way, the affair triggered an unprecedented backlash because it revealed the extent to which Mahathir's inner-circle controlled the police, judiciary and attorney general's office. As the 1999 elections approached, a multi-ethnic multi-party coalition called the Barisan Alternatif (BA, "Alternative Front") emerged led by Anwar's wife, declaring it would contest on a platform of improving governance, strengthening institutions and eradicating money politics.

For the first time since independence, Malaysian's talked seriously about BN rule coming to an end. The BA transcended ethnic divisions, uniting Chinese voters long resentful of proBumiputera policies with middle-class Malays who felt neglected since Mahathir shelved the NEP (ibid). That the BN held on owed much to the legislative and coercive apparatus at its disposal. In addition to reinstating the colonial-era Internal Security Act to imprison opposition figures without trial, Mahathir tampered with electoral procedures so that 680,000 newly-registered young voters thought to favour the BA could not vote and utilised his control over the media to shut-down newspapers and websites and embark on a propaganda campaign that played on the opposition's ethnic- and class-divisions (ibid).

Yet this was merely a reprieve, as the BNs vote share has declined ever since (Figure 12).

The exception was 2004 when Abduallah Badawi, succeeding Mahathir following retirement, lured voters with reformist pledges. Upon assuming office, however, Abdullah's cabinet, stacked with Mahathir's old guard, blocked promised reforms, leading to unprecedented electoral losses in 2008. Abduallah was succeeded by Najib Razak, a hard-line politician in Mahathir's mould. Exemplifying Malaysia's new vulnerable authoritarian coalition, he employed unsavoury measures following another disastrous election in 2013 , reimprisoning Anwar on the same charges and fostering a disconcerting return to identity politics by blaming electoral losses on a "Chinese tsunami" rather than what was really a middle-class one. 
With fresh elections in late-2017 or 2018, Najib is making overtures to the Party Islam SeMalaysia (PAS) - the largest Malay-dominated party in the opposition, whose leaders he once dismissed as Islamic fundamentalists - in the name of Malay-Muslim unity, submitting a strict Islamic penal code bill to parliament originally proposed by PAS and, if the widelycirculated rumours are true, channelling RM90 million to PAS through Affinbank, a UMNOlinked bank implicated in the 1MDB scandal (Gomez 2016). Demonstrating the ephemeral nature of Malaysian politics, PAS is also being exhorted to remain in the opposition by a curious but potentially powerful alliance - whose only shared-interest is unseating Najib between Anwar's National Justice Party, which he nominally leads from prison, and the new Bersatu party formed by the politically-resurgent Mahathir, who imprisoned Anwar in the first place. Knowing it can be the kingmaker for either coalition, PAS is auctioning itself to the highest bidder, fostering an unpredictable political climate as elections approach.

\section{Figure 12. Malaysian Parliament}

\section{Malaysian parliament}

Number of seats won

$\begin{array}{llll}\text { Barisan } & \text { Pakatan Rakyat } & \text { Pan-Malaysian } \\ \text { Nasional (BN) } & \begin{array}{l}\text { Democratic Action } \\ \text { Islamic Party (PAS) }\end{array} & \text { Party (DAP) } & \begin{array}{l}\text { National Justice } \\ \text { Party (PKR) }\end{array}\end{array}$

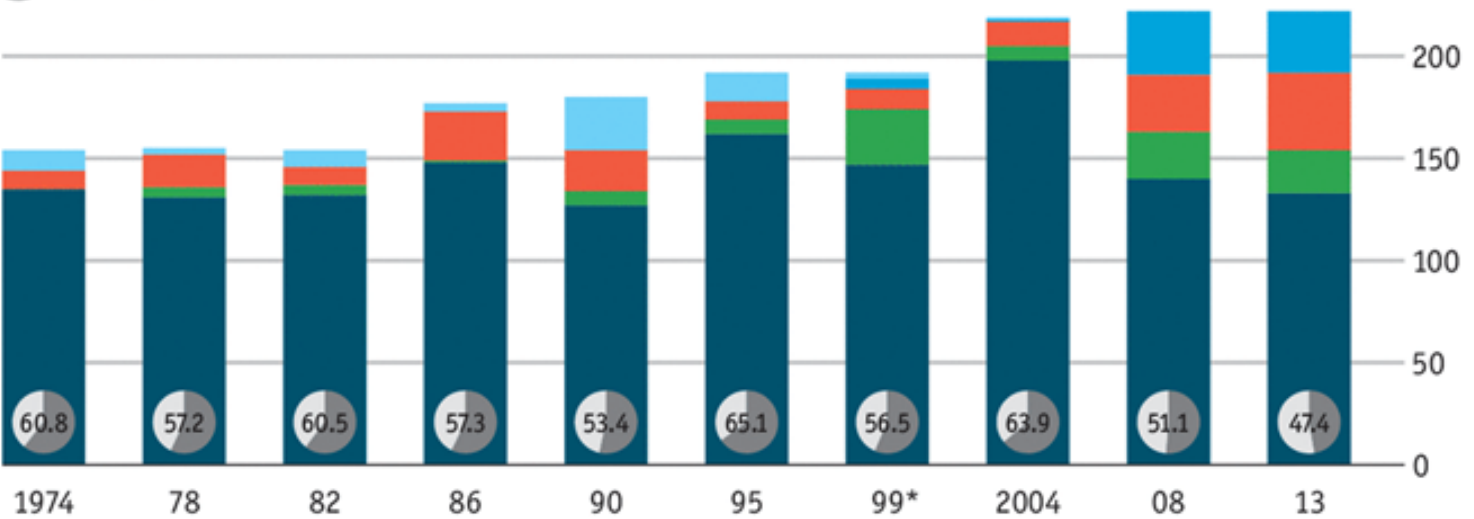

Source: Economist (2015) 


\section{Towards Competitive-Clientelism}

While the $\mathrm{BN}$ is currently a vulnerable authoritarian coalition, we predict that this will not be the case for much longer, as Malaysia's political settlement demonstrates increasing competitive-clientelist tendencies (Figure 13). Haemorrhaging middle-class support, the BN is reliant on working-class Malays, with the result that low-level actors - particularly UMNO leaders at divisional and branch levels, as well as non-party brokers - have become influential due to their importance in distributing patronage and mobilising voters (Weiss 2016). More generally, the strength of lower-level actors as voting blocs is forcing the BN to unveil populist measures before elections. Unveiling his 2012 budget, Najib, who doubles up as Finance Minister, announced that 1.4 million civil-servants would receive salary increases, that low-income households would be given RM500 and that students - an oppositionleaning demographic - would receive book vouchers. Forced into doling out these goodies by Malaysia's shifting political settlement, the $\mathrm{BN}$ is increasingly dependent on illicit money for campaigning and vote-buying, which only exacerbates the collusive state-business relations that the middle-classes seek to eradicate. This is exemplified by the scandal surrounding the $\$ 681$ million that 'mysteriously' appeared in Najib's bank account before the 2013 elections, which is rumoured to have been siphoned off from 1MDB, a state investment fund he chaired (Gomez 2016).

Figure 13. Malaysia's Political Settlement, 1996-Present

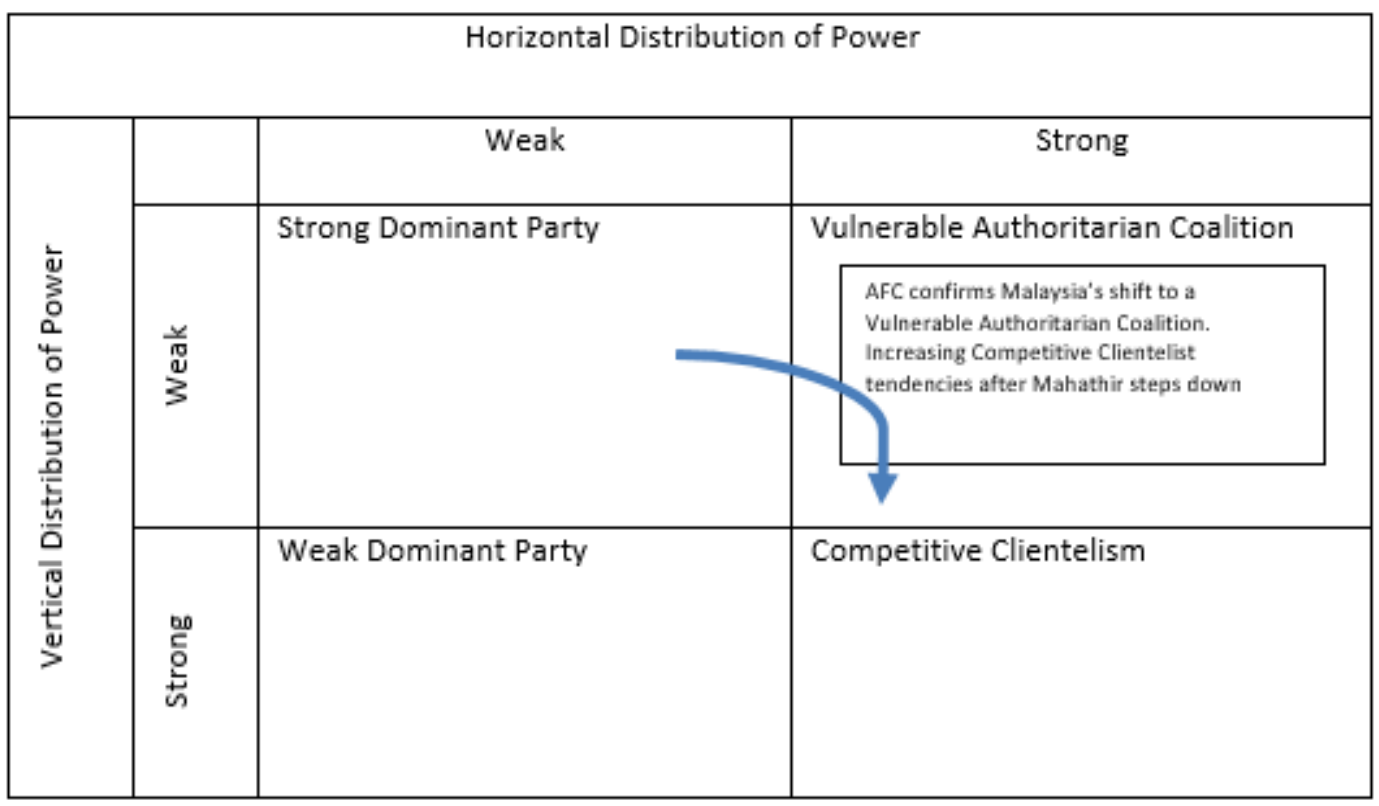

Source: Our illustration 


\section{Rents Space}

Two trends have characterised Malaysia's rents space during its deceleration episode, both linked to its political settlement. First, the magician sector has declined markedly. The textiles industry has contracted, with average growth rates of $-6.4 \%$ between 2000 and 2010, while electronics fared little better, averaging an anaemic 0.9\% (Rasiah 2012). While this process accelerated after the AFC, when investors questioned the dynamism of SoutheastAsian economies, it started in the late-1980s as Malaysia entered a "suffocating structural squeeze" (Ritchie 2005:746). On the one hand, rising salaries were prompting MNCs in assembly-based industries to relocate to China and Vietnam, which offered similar incentives and infrastructure but lower wages; on the other, Malaysia could not compete in higher value-added activities with Singapore and the NICs.

Underpinning this squeeze was the lack of strong local ancillary industries to foster linkages, and this is where the link with Malaysia's political settlement come in. Unlike the NICs, Malaysia has avoided nurturing indigenous firms through industrial policy because Chinese capitalists would have benefitted. As Ritchie (ibid:753) argues, "the exception that proves this rule is Penang", as the majority of its population is Chinese, which has allowed the state government to foster linkages between local and foreign firms "without fear of upsetting delicate communal balances". Bumiputera suppliers, meanwhile, are almost non-existent because Malays prefer operating in protected rentier and powerbroker sectors such as extractives, finance, trading, infrastructure and construction, which offer easy profits (Gomez et al. 2013). The BN tried to remedy this situation with its 1988 Vendor Development Programme, which sought to increase inputs sourced from SMEs. However, it succumbed to ethnic politics, as the approved Bumiputera suppliers were whollyuncompetitive, even by Malaysian standards.

The failure of private Malaysian companies led to the state purchasing non-performing loans from them through the asset management company Danaharta, and the replacement of private managers by state managers. Thus, the post-AFC phase was characterised by "renationalisation and a return to state ownership in the form of government-linked corporations (GLCs) as a proxy for Malay corporate ownership" (Tan 2014:160). GLCs accounted for over $50 \%$ of the market capitalisation of the stock market by the 2000 s. As 
Tan (2011:171) argues, "the emergence of GLCs may be seen as a return to proxy ownership of corporate equity by the state on behalf of Malays in the context of the historic failure of numerous high profile Malay entrepreneurs and reflected the failure of domestic companies to move into high technology sectors in the face of increasing competition". GLCs were mostly in powerbroker sectors such as utilities, transportation, banking and retail, and their dominance crowded out private investment. One important reason for the failure of the Malaysian state to foster a domestic capitalist class was that, unlike South Korea, subsidies provided to Malay entrepreneurs did not have performance requirements. Further, lack of skills and previous learning base in the Malay entrepreneurial class meant the government could not address lack of absorption of the complex organisational and production processes in the private sector necessary for industrial upgrading (Lall 1995). ${ }^{5}$

Figure 14. Malaysia's Export Structure, 1996

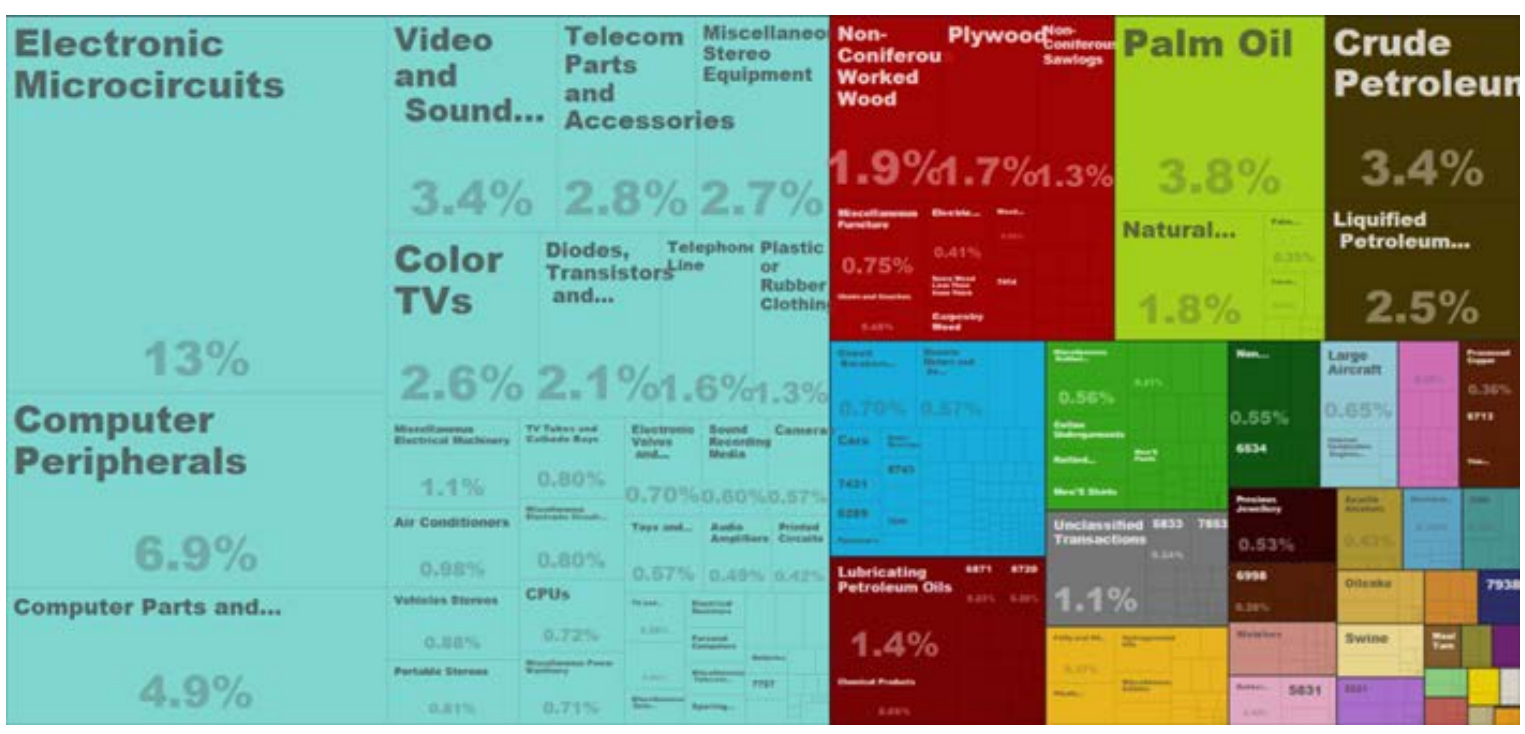

Source: Atlas of Economic Complexity, http://atlas.cid.harvard.edu/, accessed 15/08/2016

\footnotetext{
${ }^{5}$ The failure of Malay companies is reflected in ownership pattern. In 2008, seven of the ten largest Malaysian companies were state-owned. Not one Malay company featured in the largest twenty companies (Tan 2011).
} 
Figure 15. Malaysia's Export Structure, 2013

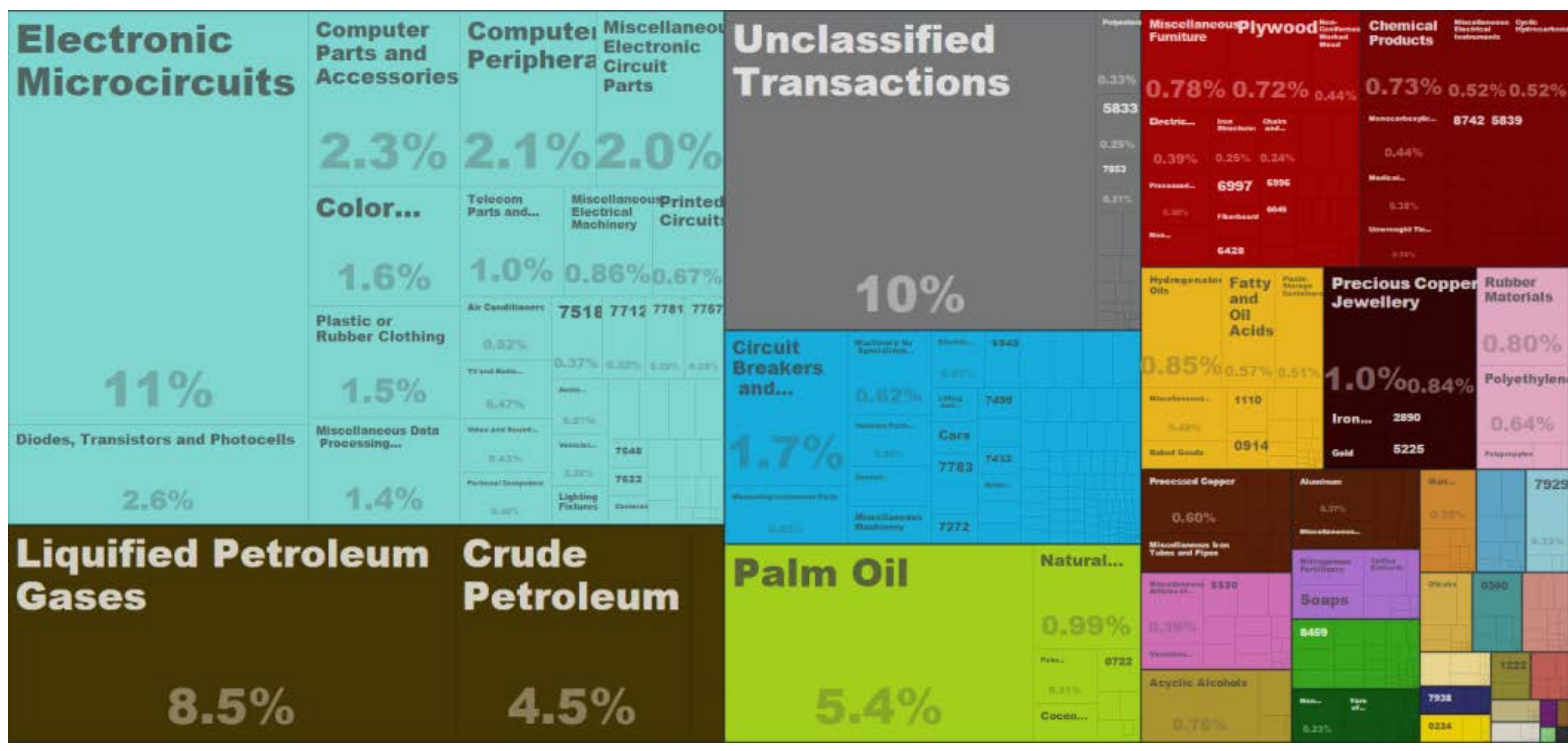

Source: ibid

The second and related trend is a resurgence of rentiers. This has resulted in a reversal in structural transformation, with declines in textiles and electronics accompanied by increases in petroleum and palm oil (Figures 14 and 15). Palm oil's resurgence is pertinent because it is intimately linked to the political settlement. To further its restructuring goals, the BN initially turned it into a workhorse sector, using trust agencies to purchase foreign plantations; land was then parcelled out through schemes like the Federal Land Development Agency (FELDA). FELDA was Malaysia's biggest grower by 1990, lauded for integrating smallholders into production (Cho 1999). Since then, however, and in the context of a weakening $\mathrm{BN}$, production has become rentier-dominated. Reliant on private money to bankroll elections, Sarawak's Chief Minister, cooperating with UMNO elites, has granted enormous concessions in Malaysian Borneo to politically-connected businessmen (Cramb 2011). In exchange for receiving long-term leases at well below market prices, or often for free, they channel donations to the Minister's Pesaka Bumiputera Bersatu party and the BN more broadly. By 2011 it was estimated that 198,882 hectares, an area three times the size of Singapore, had been allocated in this way. This heralds a radical transformation of the sector since 1990 , when 23,000 hectares were cultivated, the majority under FELDA-type schemes (ibid). 


\section{Deals Space}

Up to the AFC, the BN got its dualistic deals strategy more-or-less right, striking a reasonable balance - less so under Mahathir - between sustaining growth with open-ordered deals to magicians while restructuring society with closed-ordered deals to rentiers and powerbrokers. Owing to recent shifts in Malaysia's political settlement and rents space, however, this strategy is unravelling, with policies and institutions that were once successful in driving growth and fostering ethnic harmony becoming counterproductive. For one, the heady mix of declining magicians, resurgent rentiers and a vulnerable authoritarian coalition is making Malaysia's deals space more closed. This is exemplified by the shady patronage deals, land leases and interlocking shareholdings that have transformed palm oil.

Malaysia's automotive industry also provides a clear example of the how the dualistic deals strategy has become a constraint on growth over time, as powerbrokers were created in industries that are usually magician domains. In 1982, Mahathir established Proton to produce Malaysia's first national car. The aim was to accelerate industrialisation and strengthen the economic position of bumiputeras by securing participation in supporting industries (Gomez and Jomo 1997). Proton was protected by general automotive tariffs and a variety of additional measures. Notably, the government encouraged the development of component suppliers with strong bias towards bumiputeras, which were of poor quality and high costs. As such, Proton cars have been a failure both in export and domestic markets, and in the first decade of the 2000s it was operating at half capacity and incurring substantial losses (Natsuda and Thoburn 2012). Unlike Thailand's automotive industry, which functioned as a successful magician sector, Malaysia's behaved like a powerbroker, operating under non-competitive market structures in a closed deals environment, unable to sell in export markets.

Of even more concern, the ordered deals that have underpinned Malaysia's growth trajectory are slipping, with disorderly deals emerging. Oil is an example. Deals have been closed - extremely so - since the 1974 Petroleum Development Act gave Petronas exclusive rights to exploit Malaysia's reserves (Cho 1999). Nonetheless, deals were highly-ordered, with Petronas earning a reputation as one of the world's best-managed NOCs, staffed with capable technocrats who secured favourable production-sharing agreements (Jesudason 
1990). Yet the weakening of Malaysia's political settlement has led to increased "political meddling", with Petronas deployed to prop up flagship Bumiputera projects including Proton, provide energy subsidies to politically-connected firms and suppress the opposition by halting royalty payments to oil-producing regions whenever opposition parties are elected (Doraisami 2015). As the BN has become reliant on Petronas as a patronage tool, management of the sector has concomitantly declined, demonstrated by the BNs disregard of its National Depletion Policy. Unveiled in 1980 to manage reserves, production was meant to be capped at 270,000 barrels per day, a far cry from the 603,000 currently being produced.

The negative effect of the emerging disordered deals environment is mostly clearly reflected in the non-recovery of the investment rate since the AFC as we have seen in Figure 3 . The stagnation of the investment rate is the crucial explanatory factor behind the growth slowdown since the AFC.

\section{Feedback Loops}

Even in the late-1980s, the BN was acutely aware of Malaysia's impending structural squeeze, with Mahathir launching an Industrial Master Plan to stimulate upgrading (Rasiah 2012). Najib is also under no illusions, warning that "we have become a successful middleincome economy, but we cannot be caught in the middle-income trap; we need to make the shift to a high-income economy or risk losing growth momentum" (World Bank 2016:1). The problem is that just when political commitment, state capacity and effective complimentary institutions are needed to implement the deep reforms required, negative feedback from the political settlement and rents space has caused institutional degradation.

Two forces are at play. First, the BNs increasing vulnerability has led it to dole out publicsector jobs to politically-influential individuals, resulting in revolving door patronage appointments (Gomez et al. 2013). Even macroeconomic institutions are under threat. The Finance Ministry has been compromised ever since Najib took on the dual role of Prime Minister and Finance Minister, while the long-serving and internationally-lauded Central Bank Governor, Zeti Aziz, was due to be replaced by a political appointee until Najib's recent U-turn. Second, bureaucratic performance has been undermined by quotas requiring a ratio 
of 10:2:1 for Malays, Chinese and Indians (ibid). UMNO elites accept these quotas are undermining performance but will not remove them because they are popular with working-class Malays, on whose support they now depend. It is the same with education, where quotas allow Malays to attend university but exclude non-Malays who leave Malaysia in search of tertiary education, sometimes never to return (Rasiah 2012). This is a concern, given Malaysia's shortage of engineers and researchers, and the urgency with which it must upgrade.

\section{Thailand}

\section{Political Settlement}

Thailand retained a competitive-clientelist settlement for much of its deceleration episode, though the fissures it generated became increasingly virulent, triggering a shift to a vulnerable authoritarian coalition (Figure 16). As in Malaysia, the AFC - and particularly the unwieldy six-party ruling coalition's inept response to it, which entailed months of dithering over the terms of an IMF bailout before finally accepting one on even more stringent terms - triggered an outpouring of public anger and the resignation of Prime Minister Chavalit Yongchaiyudh (Khan 2010). Spurred on by bringing down Chavalit's administration, an alliance of social forces steered by the middle-classes pressured an incoming seven-party coalition led by Chuan Leekpai into appointing a constitution-writing committee stacked with civil-society actors. Informed by notions of good governance, the constitution envisaged a modern political system where parties would compete through manifestos rather than money (ibid). The electoral system was altered to favour large parties, election spending was capped, MPs were prevented from defecting before elections and monitoring bodies were established, notably the Electoral Commission, Constitutional Court and National Counter Corruption Commission.

It was within this context that Thaksin Sinawatra, a business magnate with interests in telecommunications, media and transport, led his Thai-Rak-Thai (TRT) party to success in 2001, the first elections under the new constitution. Also a first, Thaksin won on the basis of a coherent manifesto that pledged "new thinking, new ways, for all Thais" (Hewison 2010:111). His policy platform united a remarkably eclectic mix of voters, unmatched before or since. The middle-classes, new rich and Sino-Thai capitalists all flocked to Thaksin 
because he railed against IMF measures while he struck a chord with poor, predominantly rural voters by promising spending programmes and credit to SMEs. Another first, he followed through with his pledges, launching the Village and Community Fund which provided low-interest loans to entrepreneurs and small enterprises in every village, and the Universal Health Scheme which offered healthcare for 30 baht within a year of assuming office (ibid). By 2002 these schemes were reaching 52 million beneficiaries, and Thaksin was riding a wave of popularity.

Thaksin's stance changed dramatically as he neared his second term. The "nationalist shibboleth" that swept him into power was dissipating; his unwieldy coalition had put aside its differences to deal with the AFC, but tensions surfaced as the economy recovered, particularly over escalating rural spending (ibid:512). A political chameleon, Thaksin reinvented the TRT as the 2005 elections approached. Espousal of economic nationalism was dropped for a populist platform that positioned him as a defender of the poor (Khan 2010). A stunningly successful strategy, it produced the most crushing victory in Thailand's history. Thaksin won 375 of 500 seats, his numbers swelling as smaller parties joined his coalition. Within this context, Parliament became a place for the TRT to "talk shop" and process legislation unopposed, with Thaksin's behaviour becoming increasingly authoritarian as he lavished business opportunities on cronies and placed allies within the clutch of institutions created to provide checks and balances (Hewison 2010:123).

Furious at a resurgence of money politics, the middle-classes formed the People's Alliance for Democracy, a movement that enjoyed support amongst the business community, military and Palace. It launched non-stop street demonstrations during 2006, eroding Thaksin's ability to govern. Finally, on September 19th, claiming to be restoring stability, the military launched a coup. Hurling Thailand back into its familiar pattern of coups, constitutions and elections, the junta rewrote the constitution in ways that unravelled Thaksin's control over the political system, then called an election in 2007 (Marshall 2014). The political tumult that has occurred since is too complex to recount in detail, but has followed a similar pattern. Broadly speaking, it involved the re-election of Thaksin-linked parties in 2007, 2011 and 2014, the consequent mobilisation of anti-Thaksin "yellow shirt" protesters in 2008, 2011 and 2014 and the overthrow of Thaksin-linked parties in 2008 and 
2014, followed by inevitable pro-Thaksin "red shirt" protests. Such are the divisions in Thailand's political settlement that these rifts between yellow/red, rural/urban, for/against Thaksin are now almost unbridgeable, with the result that incoming coalitions struggle reconciling the interests of business- and middle-classes on the one hand and factions Thaksin mobilised on the other.

\section{Vulnerable Authoritarian Coalition (2014-Today)}

It is in this context that the military launched its third coup since 1996. Declaring that feuding had left Thailand on the brink of civil war, it ousted a government led in Thaksin's absence by his sister Yingluck, which had riled the establishment with an amnesty bill pardoning Thaksin. Just as critically, the coup was launched when 88-year-old King Bhumibol's health was deteriorating rapidly, prompting fears of an unfavourable succession. Even though Prince Vajiralongkorn was constitutionally next-in-line, the military was extremely wary of this as he is a close friend of Thaksin (Marshall 2014). Fearing that Thaksin's exile would be lifted if Vajiralongkorn became King, it was rumoured the coup was a mechanism for engineering Princess Sirindhorn as successor.

While coups have been a constant feature of Thailand's trajectory, this had several features that distinguish it from others, leading us to conclude that the political settlement has shifted to a vulnerable authoritarian coalition (Figure 26). In contrast to 2006 and 2008, when the military made relatively minor constitutional amendments before presiding over elections weighted against Thaksin-aligned parties, this time it has systematically restructured the political system in ways that unravels the electoral system and prevents future "parliamentary dictatorships" (Kanchoochat 2014). A military-dominated Constitution Committee was tasked with drafting a new constitution. As expected, the draft curbed the authority of elected politicians and parties while enhancing the power of appointed officials, oversight bodies and a military-dominated upper-chamber, all of which were mechanisms for extending military rule. The charter caused an outcry, prompting the junta to respond with Orwellian-esque "attitude adjustment" sessions for critics at remote military bases.

After repeated postponements, a referendum was held in late-2016. Responding to a heavy police presence and a ban on campaigning against the draft, many Thais stayed at home, 
resulting in a turnout of only $55 \%$, of which $61.45 \%$ voted in favour. Factions loyal to Thaksin cried foul, citing voting irregularities and the fact that 700,000 bureaucrats and soldiers had been deployed to help "explain" the draft to voters, while the US, UN and EU complained that observer groups were prevented from monitoring the process (Economist 2016). These criticisms were batted away, with the junta heralding the vote as a decisive victory and promising elections in 2017.

King Bhumibol died two months after the referendum, plunging Thailand back into a period of uncertainty just when it had regained some clarity. A year of mourning was called by Prime Minister Prayuth, while the junta shelved proposed elections to oversee the transition. Following a rapprochement of sorts in the months before the King's death, Prayuth announced that Vajiralongkorn would be Thailand's next monarch but that his accession would be delayed for an unspecified period of time, feeding rumours that the establishment was assessing other options. Despite the constitution stipulating that Vajiralongkorn, the undisputed heir, should have immediately succeeded his father, seven tense weeks passed before the leader of the national assembly invited him to take up the throne. The official explanation was that the Prince needed time to grieve his father; in reality, however, the delay owed to behind-the-scenes negotiations establishment figures sought guarantees on key issues such as Thaksin's ongoing exile. Vajiralongkorn ultimately accepted the offer and ascended to the throne, but immediately caught the junta flat-footed by rejecting elements of its new constitution that restrict his influence, initiating what may be a long, drawn-out power-struggle (Economist 2017). As such, the junta is even more committed to staying in power than it was before, demonstrated by its reticence to offer even a vague timetable for the elections it proposed before Bhumibol's death, with the King's proposed constitutional amendments offering a convenient excuse to delay elections until at least 2018. 
Figure 16 Thailand's Political Settlement, 1996-Present

\begin{tabular}{|c|c|c|c|}
\hline \multicolumn{4}{|c|}{ Horizontal Distribution of Power } \\
\hline \multirow{4}{*}{ 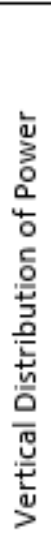 } & & Weak & Strong \\
\hline & & Strong Dominant Party & Vulnerable Authoritarian Coalition \\
\hline & 并 & & $\begin{array}{l}\text { Possessing a Competitive Clientelist Political } \\
\text { Settlement for much of its deceleration } \\
\text { episode, Thailand has had a Vulnerable } \\
\text { Authoritarian Coalition since its most recent } \\
\text { coup in } 2014\end{array}$ \\
\hline & 点 & Weak Dominant Party & Competitive Clientelism \\
\hline
\end{tabular}

Source: Our illustration.

\section{Rents Space}

Thailand is also finding itself squeezed between low-wage and high-technology competitors. However, there has not been quite the same exodus of magicians, owing to the (limited) linkages forged with predominantly Sino-Thai suppliers through local content policies launched in the 1980s (Doner 2009). Unlike in Malaysia, where ethno-political considerations prevented the $\mathrm{BN}$ from promoting indigenous firms, Thailand's political settlement has allowed - even encouraged - politicians to nurture Sino-Thai capitalists, both as a means of stimulating growth and as a source of personal enrichment (Raquiza 2012). This has generated relatively strong linkages with foreign magicians, explaining their continuing - and, in the case of automobiles, increased - presence within Thailand's rents space and export structure (Figures 17 and 18). Equally, there has not been the resurgence of rentiers witnessed in Malaysia, owing not just to the fact that Thailand has never been as well endowed with natural resources, but that the one resource it did have - land - is exhausted, in contrast to Malaysia's vast frontier in Sabah and Sarawak. 
Figure 17. Thailand's Export Structure, 1996

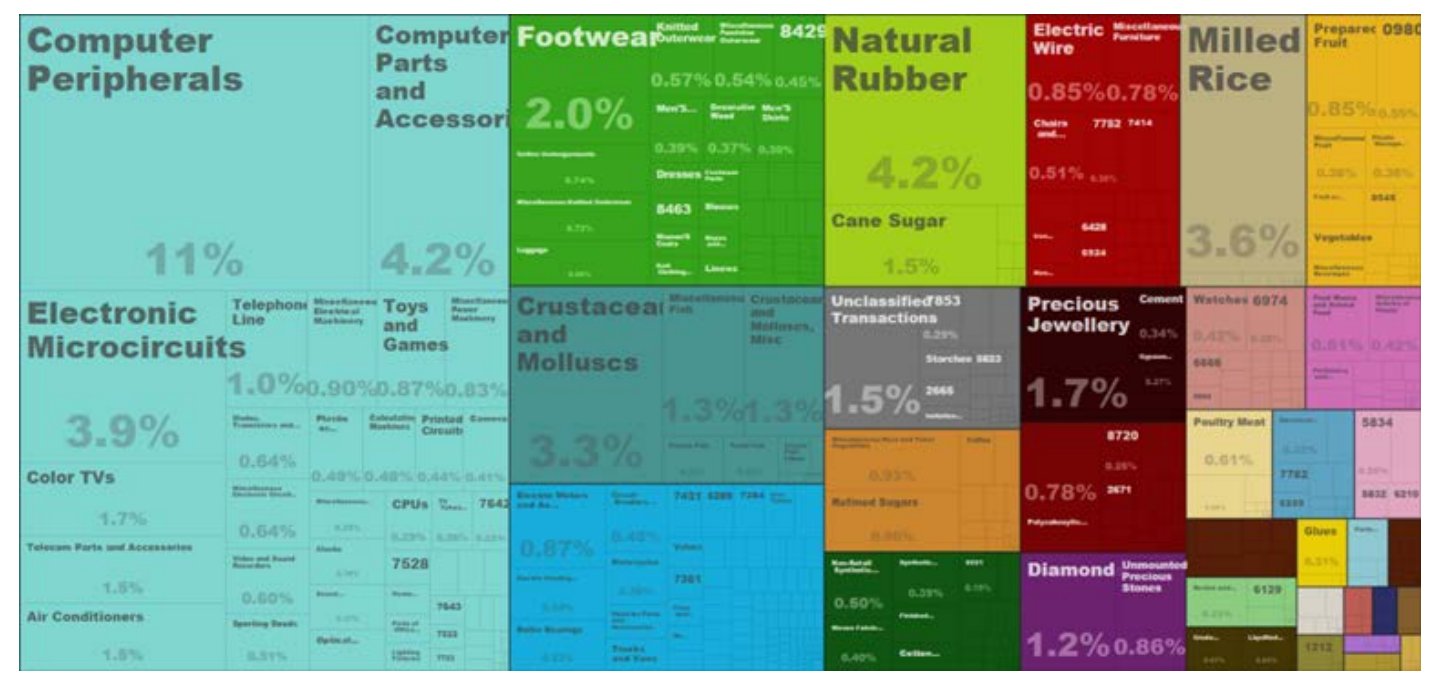

Source: Atlas of Economic Complexity, http://atlas.cid.harvard.edu/, accessed 15/08/2016

Figure 18. Thailand's Export Structure, 2013

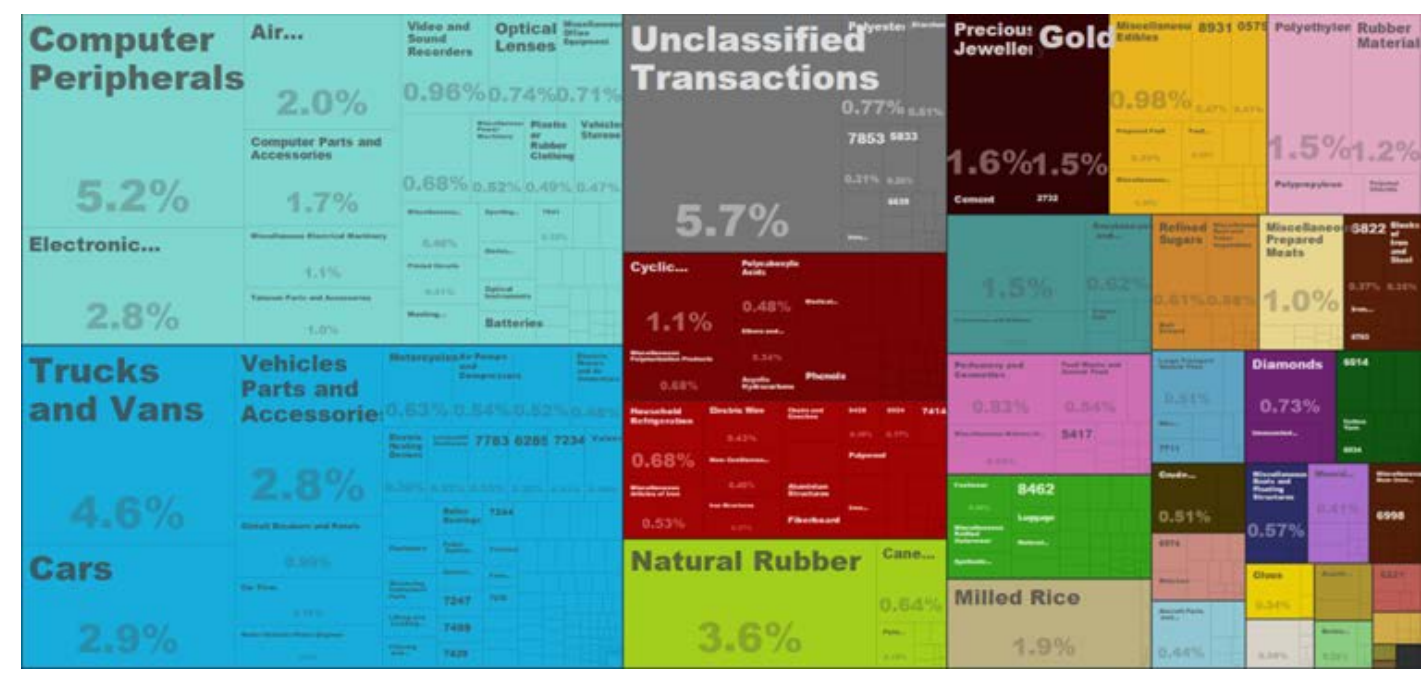

Source: ibid

\section{Deals Space}

Where deals became disordered during the 1990s, Thaksin reordered them by reforming the bureaucracy. He strengthened core institutions such as the Central Bank and Ministries of Finance, and revitalised the BOI and NESBD after years of neglect (Kanchoochat 2014). Yet even here Thaksin clashed with the establishment, as he demanded an ideational shift. Thailand's bureaucracy has long been relatively effective but promotions and advancement were predicated upon seniority rather than ability, whereas Thaksin implemented a public management system whereby high-performing bureaucrats were fast-tracked to the top 
(Doner 2009). Some suggest this offered a convenient way of transplanting allies into the upper-echelons of the bureaucracy, while others maintain Thaksin was committed to reform. Either way, it was another arena in which he clashed with the establishment.

Thaksin retained the broad features of Thailand's dualistic strategy, though the beneficiaries of these deals changed significantly, offering further insights into why he was overthrown. Consistent with previous administrations, Thaksin offered open-ordered deals to magicians, unveiling a cluster-based industrial policy that offered incentives and cheap credit to five priority sectors - automobiles, computers, textiles, food and tourism (Doner 2009). Thaksin focused on automobiles, believing Thailand could become a regional export hub. In 2002, he unveiled a four-year master plan offering tax incentives in exchange for meeting targets such as producing $1,000,000$ cars a year and $60 \%$ localisation. These targets were met a year ahead of schedule and several Japanese manufacturers established R\&D facilities in the country. Referring to Thailand's structural squeeze as the "nutcracker effect", Thaksin also helped domestic suppliers upgrade by establishing a National Committee on Competitiveness and instructing the BOI to promote technology development (ibid:131). ${ }^{6}$

While there was continuity for magicians, a shift occurred in the rentier and powerbroker domains. Closed-ordered deals remained the order of the day but beneficiaries were no longer establishment-linked firms; instead, deals went to Thaksin's associates. Thaksin was Thailand's major telecoms tycoon while his inner-circle had interests in construction, property, media and retail, all of which are traditional establishment industries. Deals became exceptionally closed as Thaksin channelled licenses and contracts to a coterie of TRT-linked businesses, helping them to expand at an unprecedented rate. Simultaneously, the protection afforded to establishment-linked conglomerates as a means of sustaining the political settlement was unravelled, particularly the privileges given to the CPB, whose "special status" Thaksin resented (Hewison 2010:128). These are critical insights, then, as they reveal the extent to which Thaksin "was pitted against the 'old oligarchy", and that the coup was ultimately a mechanism for "preserving the status quo" (ibid:127).

\footnotetext{
${ }^{6}$ In 2010, 53\% of the 690 companies that constituted Tier 1 suppliers were Thai or Thai majority firms, while all 1700 Tier 2 suppliers were Thai (Natsuda and Thoburn 2012).
} 
Deals remained generally ordered following Thaksin's ouster, particularly for magicians who are cocooned in Thailand's EPZs and largely insulated from political upheaval. Yet this order has been punctuated by pockets of disorder around regime changes. Thailand had five prime ministers between 2006 and 2014, resulting in constant changes on the management level of ministries and agencies as each incoming coalition rewarded its supporters in a bid keep itself in power (Kanchoochat 2014). There has been a significant reordering since 2014, however, with the junta launching major reforms in the bureaucracy. There has also been a return to a traditional dualistic deals strategy under its 20-year economic plan, which aims to transform Thailand into a first-world nation with a value-added economy, and whose provisions will be enshrined in law so that future governments are forced to implement them (The Diplomat 2016). Offering incentives to magicians such as automobiles, electronics and textiles on the one hand and powerbroker industries such as petrochemicals, chemicals and pharmaceuticals on the other, it removes subsidies from Thaksin-linked industries such as telecoms and roads.

Thailand's deals environment was relatively more ordered than Malaysia's since the AFC. This may explain why the investment rate has seen some slight recovery since its plunge during the AFC (see Figure 3), as compared to Malaysia's prolonged stagnation in the investment rate.

\section{Feedback Loops}

The shift to a vulnerable authoritarian coalition since 2014 suggests the possibility of a clear negative feedback loop from the evolving political situation to the deals space that may lead to a disordering of deals in the near future. The increasingly authoritarian nature of the current political regime could lead to push-back from excluded elites (for example, those loyal to Thaksin) while it is also possible that the pent-up frustration in the countryside, due to stark regional inequalities, spills onto the streets of Bangkok once again. While magicians have been remarkably resilient during previous periods of electoral turmoil and military coups, the lack of clarity regarding when new elections will be held as well as the continuing role of the monarchy as a key source of patronage may prolong (or worsen) Thailand's current growth deceleration episode. 


\section{Conclusions}

Both Malaysia and Thailand were seen to be part of the miracle growth economies of East Asia in the early 1990s (World Bank 1993) and fast moving into high income status. Following the Asian Financial Crisis of the mid 1990s, both countries have observed prolonged growth slowdowns, with the transition to high income status increasingly unlikely in the near future. In this paper, we offered a political economy explanation of the growth slowdown in Malaysia and Thailand in their post AFC phases. We argued that political elites in these two countries followed a dualistic deals environment in the first growth phase (that is, from the 1960s to the AFC) where they offered open ordered deals to magicians - that is, firms in the export-oriented manufacturing sector and at the same time, offered closed ordered deals to powerbrokers - mostly domestic firms operating in non-tradable sectors or in manufacturing sectors that were protected to a large extent from foreign competition (and in the case of Malaysia, as well as to rentiers). In the case of Malaysia, the dualistic deals environment was an outcome of the strong dominant party political settlement which attempted to balance the need for political stability (through rents that were created for powerful Malay groups in the society via the closed deals with powerbrokers) with the need for high rates of growth that occurred from the open ordered deals offered to magicians. In the case of Thailand, the dualistic deals environment was more a result of a shift to a competitive clientelist political settlement in the 1970s, as well as the means of securing the support of the military and monarchy to the growth strategy followed by Thai political elites.

The dualistic deals environments served Malaysia and Thailand well in the first growth phase as high growth and fast rates of structural transformation ensued with the rapid expansion of the export-oriented manufacturing sector. However, towards the mid-1990s, negative feedback loops were observed in both countries, with the political settlement in Malaysia moving from strong dominant party to a vulnerable authoritarian political settlement after the AFC, and the competitive-clientelist political settlement in Thailand becoming increasingly virulent, culminating in a shift to a vulnerable authoritarian political settlement in the 2000s. In the case of Malaysia, the closed ordered deals that were offered to Malay entrepreneurs, as a means of countering the power of Malaysia's Chinese capitalist 
class, had largely failed to create a dynamic Malay capitalist class that could compete effectively in world markets, and led to a dualistic industrial structure with multinationals operating in the export-oriented manufacturing sector and globally uncompetitive Malay conglomerates in the domestically oriented manufacturing and service sectors. In the case of Thailand, local content requirements in the automobiles and electronics sectors had created a large number of Thai companies which successfully became supplier firms to the multinationals operating in these sectors. As a consequence, Thailand observed higher rates of structural transformation, though not at the same pace as in the pre-AFC phase, than Malaysia in their respective growth deceleration episodes. In both countries, the dualistic deals environments had increasingly become patronage based and increasingly disordered after the AFC, and as a consequence, limited the possibility of high growth returning to Malaysia and Thailand after the economic downturn caused by the AFC.

Our findings suggest that there is nothing pre-ordained about the movement from low income to high income status, even for countries such as Malaysia and Thailand who have had remarkable growth success for many years. The "middle income trap" in these two countries may then be a reflection of the clientelist nature of the political settlement prevailing in Malaysia and Thailand, where political elites have little incentive to enact institutional reforms needed for further growth and structural transformation. For Malaysia and Thailand to break out of the middle-income trap, it would be necessary for them to move out of the clientelist nature of the current political settlement that both countries find themselves in. The outlook for this to happen does not look positive for Malaysia and Thailand in the foreseeable future. 


\section{References}

Cherif, R. and Hasanov, F. (2015), The Leap of the Tiger: How Malaysia can escape the Middle Income Trap, IMF Working Paper no. 15/131.

Cho, G. (1990) The Malaysian Economy: Spatial Perspectives, Routledge, London

Cramb, R. (2011) "Re-Inventing Dualism: Policy Narratives and Modes of Oil Palm Expansion in Sarawak, Malaysia", Journal of Development Studies, vol.47, no.2, pp.274-293

Doner, R. (2009) The Politics of Uneven Development: Thailand's Economic Growth in Comparative Perspective, Cambridge University Press, New York

Doner, R. and Ramsay, A. (2000) "Rent-Seeking and Economic Development in Thailand", in Rents, Rent-Seeking and Economic Development: Theory and Evidence in Asia, Khan, M. \& Jomo, K. (eds), Cambridge University Press, Cambridge, pp.145-281

Doraisami, A. (2015) "Has Malaysia really escaped the resource curse? A closer look at the political economy of oil revenue management", Resources Policy, vol.45, pp.98-108

Economist. (2015) Economic Malays,

http://www.economist.com/blogs/graphicdetail/2015/09/malaysia-graphics [Accessed: $10 / 11 / 2016]$

Economist. (2016) Thailand votes for a new constitution, http://www.economist.com/news/asia/21704593-charter-further-consolidates-powerarmy-thailand-votes-new-constitution [Accessed: 22/11/2016]

Economist. (2017) Thailand's new king rejects the army's proposed constitution, http://www.economist.com/news/asia/21714298-all-wrong-reasons-thailands-new-kingrejects-armys-proposed-constitution [Accessed: 27/02/2017] 
Gomez, E. (2004) The State of Malaysia: Ethnicity, Equity and Reform, Routledge, Abingdon. pp.1-29

Gomez, E. \& Jomo, K. (1997) Malaysia's Political Economy: Politics, Patronage and Profits, Cambridge University Press, Cambridge

Gomez, E., Saravanamuttu, J. \& Mohamad, M. (2013) The New Economic Policy in Malaysia, ISEAS Publishing, Singapore

Gomez, E. (2016) "Resisting the Fall: The Single Dominant Party, Policies and Elections in Malaysia", Journal of Contemporary Asia, vol. 46, no. 4, pp. 570-590

C. Hidalgo and R. Hausmann (2009), The Building Blocks of Economic Complexity, PNAS, Vol. 106, No. 26, pp. 10570-10575.

Hewison, K. (1997) Political Change in Thailand: Democracy and Participation, Routledge, London

Hewison, K. (2010) "Thaksin Shinawatra and the reshaping of Thai politics", Contemporary Politics, vol.16, no.2, pp.119-133

Jesudason, J. (1990) Ethnicity and the Economy: The State, Chinese Business, and Multinationals in Malaysia, Oxford University Press, Oxford

Kar, S. and K. Sen (2016), A Political Economy Theory of India's Growth Episodes, London: Palgrave Macmillan.

Kanchoochat, V. (2014) Coalition Politics and Reform Dynamics in Thailand, Discussion Paper 13-26, Institute for Policy Studies, Tokyo

Khan, M. (2010) Political Settlements and the Governance of Growth-Enhancing Institutions, Mimeo 
Kharas, H. and Kohli, H. (2011) "What is the middle income trap, why do countries fall into it, and how can it be avoided?" Global Journal of Emerging Market Economies 3.3, pp. 281-289.

Marshall, A. (2014) A Kingdom in Crisis: Thailand's Struggle for Democracy in the TwentyFirst Century, Zed Books, London

Natsuda, K. and Thoburn, J. (2012), "Industrial policy and the development of the automotive industry in Thailand", Journal of the Asia Pacific Economy, pp.1-25.

North, D. C., J.J. Wallis, and B. R. Weingast. 2009. Violence and social orders: a conceptual framework for interpreting recorded human history. New York: Cambridge University Press.

Pritchett, L. and Werker, E. (2012) Developing the guts of a GUT (Grand Unified Theory): Elite commitment and inclusive growth, Working Paper No.16, Effective States and Inclusive Development Research Centre, Manchester

Pritchett, L., Sen, K. and Werker, E. (2017), Deals and Development: The Political Dynamics of Growth Episodes, Oxford: Oxford University Press.

Raquiza, A. (2012) State Structure, Policy Formation and Economic Development in Southeast Asia: The Political Economy of Thailand and the Philippines, Routledge, Abingdon

Rasiah, R. (2012) "Is Malaysia's electronics industry moving up the value chain?", in Malaysia's Development Challenges: Graduating from the Middle, Hill, H., Yean, T. \& Zin, R. (eds), Routledge, Abingdon, pp.194-211

Ritchie, B. (2005) "Coalitional Politics, Economic Reform, and Technological Upgrading in Malaysia", World Development vol.33, no.5, pp.745-761

Rodrik, D. (2016), "Premature Deindustrialization", Journal of Economic Growth, Vol.21, pp.1-33. 
Sen, K (2013), "The Political Dynamics of Economic Growth", World Development, 2013, Vol. 47, pp. 71-86.

Tan, J. (2014), "Running out of steam? Manufacturing in Malaysia", Cambridge Journal of Economics, Vol.38, pp.153-180

The Diplomat. (2016) Can Thailand's Junta Reverse Thailand's Economic Decline?, http://thediplomat.com/2016/03/can-thailands-junta-reverse-its-economic-decline/

Unger, D. (1998) Building Social Capital in Thailand: Fibres, Finance and Infrastructure, Cambridge University Press, New York

Warr, P. (1993) The Thai Economy in Transition, Cambridge University Press, Cambridge

Warr, P (2011), ' Thailand, a nation caught in the middle-income trap', East Asia Forum

Weiss, M. (2016) “Payoffs, Parties, or Policies: 'Money Politics' and Electoral Authoritarian Resilience", Critical Asian Studies, vol.48, no.1, pp.77-99

World Bank (1993), The East Asian Miracle, World Bank, Washington D.C.

World Bank (2012), World Development Report 2013: Jobs. Washington, DC: World Bank. World Bank. (2016) Middle-Income Trap: Myth or Reality?, Larson, G., Loayza, N. \& Woolcock, M. (eds.), World Bank, Kuala Lumpur 